\title{
ANAXAGOROVSKÁ PRÓZA, RÉTORIZUJÍCÍ HIPPOKRATOVSKÉ SPISY A OTÁZKA P̌̌EDPLATÓNSKÉ RÉTORICKÉ TEORIE
}

\section{Jiří Klouda}

Poněkud zvláštní okolnost, že první dochovaný výskyt slova rétorika (@̣ๆo@ıxท́) se nalézá v Platónově dialogu Gorgias a že ho pronáší platónský Sókratés, je historikům řecké literatury známa již delší dobu. ${ }^{1}$ Avšak teprve na samém sklonku 20. století se objevily pokusy o radikální zhodnocení tohoto faktu, v nichž byl Platón interpretován nejen jako pravděpodobný původce nového výrazu, ale též jako myslitel, který podstatně přispěl k založení rétoriky jako samostatné disciplíny. ${ }^{2}$ To se na první pohled může zdát paradoxní, nebot' filosofická i filologická tradice často nedokázala nalézt dostatečný odstup od sugestivní Platónovy argumentace, v níž se Sókratés jeví především jako neúprosný kritik rétoriky. ${ }^{3}$ Proto následující studii započneme představením hlavních argumentů, z nichž teze o platónském původu rétoriky vychází, a poté budeme tuto pozici konfrontovat s rétorizujícími texty dochovanými ve sbírce lékařských spisů Corpus Hippocraticum, jež svým počtem i datací do 5. stol. př. Kr. představují významné, i když často přehlížené svědectví o intelektuálním kontextu, v němž se řecká rétorika jako zvláštní disciplína rodila.

1 Viz např. W. Kroll, Rhetorik, in: G. Wissowa (vyd.), Paulys Realencyclopädie der classischen Altertumwissenschaft, Suplementband, VII, Stuttgart 1940, sl. 1039.

2 Th. Cole, The Origins of Rhetoric in Ancient Greece, Baltimore - London 1991, 1995²; E. Schiappa, The Beginnings of Rhetorical Theory in Classical Greece, New Haven - London 1999. K diskuzi této pozice v současném bádání viz např. M. Gagarin, Background and Origins: Oratory and Rhetoric before the Sophists, in: I. Worthington (vyd.), A Companion to Greek Rhetoric, Malden (MA) 2007, str. 27-36, nebo (kritičtěji) L. Pernot, La rhétorique dans l'antiquité, Paris 2000, str. 38-41. K pozadí renesance zájmu o rétoriku na Západě ve druhé polovině 20. stol. srv. K. Boháček, Aristotelés a Nová rétorika, in: Aither, 11, 2014, str. 100-113.

3 Jako ukázka masivní identifikace s Platónovou pozicí ze strany jeho moderních vykladačů může posloužit tvrzení Františka Novotného z jeho Úvodu k překladu dialogu Gorgias, Praha 1993, str. 8: „Rétorika ... je tu předvedena před soudnou stolici ethiky, je souzena a odsouzena: její domnělá moc se ukáže nicotnou a nicotné je i domnělé štěstí, které přináší člověku." Podle tohoto překladu je dialog Gorgias citován i níže v textu (občas s drobnými úpravami). 
Jestliže schopnost přesvědčivé veřejné promluvy patřila k samozřejmým atributům už homérských hrdinů, o rétorice mluvíme teprve tehdy, kdy je tato schopnost systematizována, teoretizována, a tak převedena na sadu pravidel, podle nichž má být promluva konstruována. Tento proces se odehrává za účelem jednak snazšího didaktického přenosu, jednak dalšího zefektivnění užívaných prostř̌edků, nebot' zformulovaná pravidla lze rychleji předávat a jasněji diskutovat. Antická doxografie rétoriky ${ }^{4}$ spojuje počátky oboru s pololegendárními postavami Sicilanů Teisiy a Koraka, od nichž měla pocházet první učebnice. My však vyjdeme z Platónovy konfrontace Sókrata s Gorgiou, tedy z pasáže dialogu Gorgias, kde se slovo rhétoriké objeví zřejmě poprvé.

Rozhovor mezi Sókratem a Chairefóntem na jedné a Gorgiou a Pólem na druhé straně začíná otázkou po tom, v jakém umění je Gorgias odborníkem, a jak je tedy třeba jej nazývat (Gorg. 448b-c). Když Pólos vychválí Gorgiovo umění jako „to ze všech nejkrásnější“, je pokárán, že neodpověděl na otázku, které je to umění, nýbrž pouze říká, jaké jest. Přitom ho Sókratés ovšem chválí, že je „,dobře připraven ke slovním výkonům“ a je ,více vycvičen v tak řečené rétorice než v dialogu“ (448d). ${ }^{5}$ Rétorika je zde tak od samého začátku spojena s tvorbou řečí a postavena do opozice vůči rozhovoru. Poté se Sókratés zeptá přímo Gorgii, „kterého umění jsi znalý a kým je proto třeba tě nazývat?“ Gorgias na to výslovně uvede, že je znalý rétoriky, a souhlasí s tím, aby byl nazýván rétorem (449a). V dalším průběhu rozmluvy pak Pólos a Gorgias akceptují Sókratovu argumentaci a podle analogie s ostatními uměními (technai) hledají pro rétoriku její specifický předmět (449d). Když poté Gorgias určí za takový předmět „,reči“ (logoi), namítne Sókratés, že řečí užívají různou měrou i ostatní obory, např. lékařství činí lidi schopné náležitě mluvit a myslet o nemoci atp. Gorgias se pak ještě poukazem, že se rétorika zabývá řečmi, které se týkají největších lidských věcí (451d7),

4 Antická svědectví, v jejichž čele ovšem stojí Platón a Aristotelés, shromáždil L. Radermacher, Artium scriptores. Reste der voraristotelischen Rhetorik, Wien 1951, str. 28-35.

5 Spojení „tak řečená rétorika“ ( nat, že Sókratés odkazuje na již fixovaný terminologický úzus; stejně dobře může zdůrazňovat akt zavedení nového výrazu, zhruba ve smyslu ,tato - říkejme jí - rétorika“. K tomu viz E. Schiappa, The Beginnings, str. 17 n., který též poukazuje na Platónovu oblibu ve výrazech končících na -ikos, z nichž velká většina se v literatuře před ním nevyskytuje (tamt., str. 15, s odkazy na speciální studie). 
snaží vymanévrovat z pozice rétoriky jako pouze jednoho z oborů, který leží principiálně na stejné rovině s ostatními, a chce jí jako předtím Pólos zajistit určité privilegované postavení vůči ostatním uměním. Tuto privilegovanost rétora však vyloží jako mocenské, vládu zajišt'ující postavení v polis, garantované schopností přemlouvat řečmi kohokoli na soudě a v občanském shromáždění (452d-e). ${ }^{6}$ Uvedené stanovisko pak Sókratés převádí na vymezení: „Rétorika je výrobkyně přemlouvání a všechna její činnost i všechen její obsah směřuje k tomuto cíli; či snad můžeš říci, že moc rétoriky má větší rozsah než to, způsobovat v duších posluchačů přemluvu?"“(453a1-5). ${ }^{7}$ Gorgias s touto charakteristikou bez výhrad souhlasí.

Následující postup rozpravy nám stačí podat už velmi stručně: jelikož stále platí, že rétorika je jedním speciálním uměním mezi ostatními, porovnává Sókratés způsob, jakým přesvědčují posluchače ostatní umění, která, jak bylo výše ukázáno, také užívají řeči. Řeč rétoriky pak na rozdíl od řečí ostatních oborů nezpůsobuje vědění, které je jako takové pravdivé, ale víru bez vědění, tedy věření, které je vůči vědění neutrální. Když Sókratés zohlední Gorgiou preferovanou politickou a soudní působnost rétoriky, formuluje doplnění, podle něhož je rétorika „výrobkyní přemluvy věrivé, ne naučné, o spravedlivu a nespravedlivu“ (455a). Tím se rétorika definitivně ocitá v oblasti etického vědění. Tento krok ovšem koliduje s Gorgiovým tvrzením o hodnotové neutralitě rétoriky, kterou podle něj lze stejně dobře využít k dobrému i zlému. Proto nemůže rétor přemlouvat kohokoli $\mathrm{k}$ čemukoli, jestliže by to bylo nespravedlivé, a rétorika nebude tím nejvyšším uměním, nebot' nad sebou musí uznat etiku. Pokud by tak neučinila a nárokovala by si ono výsostné postavení

6 Viz především Gorg. 452e1-8 s opakovanými výrazy dynamis, resp. $d y$ nasthai.

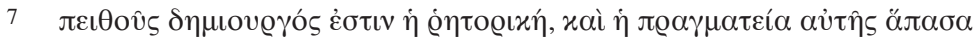

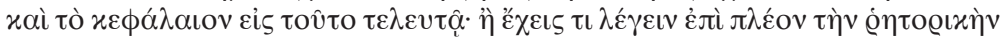

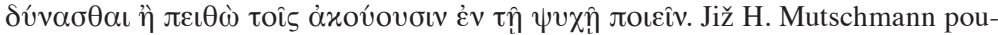
kázal na to, že se s největší pravděpodobností nejedná o definici historického Gorgii, nebot' podobným způsobem Platón provizorně definuje v Charmidu lékařství jako

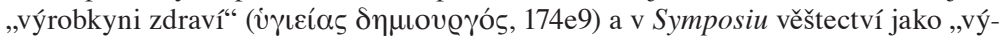

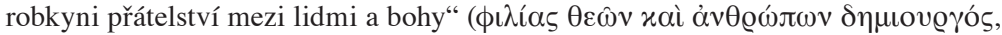
188d1), viz H. Mutschmann, Die älteste Definition der Rhetorik, in: Hermes, 53,

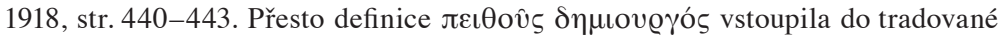
rétorické doxografie, a to nejen v přímém spojení s Gorgiou: Prolegomena ad Hermogenem ji situují do okolí intelektuálního vlivu Teisiy a Koraka (Artium scriptores, str. 30); Quintilianus, Institutio oratoria, II,15 ji spojuje s učebnicí připisovanou Isokratovi. 
v obci spojené s neomezeným přemlouváním, nebude uměním, ale pouze zběhlostí a cvikem (463b). Tuto zběhlost pak Sókratés nazývá „úlisným lahoděním“ a „klamným přeludem“ jisté části politiky. Tak jako jsou pro tělo dvě pravá umění, totiž gymnastika a lékařství, a pro duši analogicky zákonodárství a soudnictví, existují i přeludy, klamné podoby těchto oborů, které nesměřují $\mathrm{k}$ tomu, co je dobré, ale $\mathrm{k}$ př́jemnému: kosmetika je falešnou verzí gymnastiky, na lékařství parazituje kuchařství, sofistika je klamem zákonodárství a rétorika falešným soudnictvím (465 b-e).

Že Platónovo vymezení sofisty a rétora je velkou měrou preskriptivní a neodpovídá, nakolik můžeme podle dochovaných památek posoudit, běžnému dobovému úzu, není třeba podrobněji rozebírat. ${ }^{8}$ A i když domněnka, že slovo rhétoriké je Platónovým neologismem, zůstává př́ísně vzato nedokazatelná, ${ }^{9}$ samotná idea vidět v Platónovi zakladatele rétoriky stojí na hlubším základě, který na faktu prvního doloženého lexikálního výskytu nezávisí. Větší význam má totiž samotný sled argumentů v Gorgiovi. Zde lze identifikovat několik na první pohled samozřejmých kroků, jejichž zdánlivá banalita je však dána tím, že sami stojíme v Platónem založené tradici: (1) rétorika je jen jeden obor (techné) mezi

8 Slovo rhétór označuje v pátém a čtvrtém století každého, kdo aktivně promlouvá na sněmech nebo soudech, speciálně politika, který svou moc čerpá primárně z vystupování v lidových shromážděních (na rozdíl od tradičních forem politického kapitálu), a to s jistým hanlivým přídechem. K tomu viz W. Kroll, Rhetorik, sl. 1040; I. Worthington, Rhetoric and Politics in Classical Greece: Rise of the Rhetores, in: týž (vyd.), A Companion to Greek Rhetoric, str. 255-271.

9 Druhým spisem, v němž kolem poloviny 4. století př. Kr. výraz @̣ nalézáme, je Alkidamantova řeč $O$ sofistech čili autorech psaných řečí, §§ 1 a 2 (Artium scriptores, str. 135). Časové zařazení Alkidamantova textu zůstává nejasné (zvažuje se interval cca 390-360 př. Kr.), stejně tak otázka, nakolik se jeho teze o přednosti mluveného slova a improvizace vůči předem připravenému psanému textu opírá o znalost Platónova Faidra. Ale i v př́ípadě Alkidamantovy nezávislosti na dialogu Faidros je jeho řeč pokládána za současnou nebo spíš pozdější než dialog Gorgias. Dále výrazu častěji užívá už jen Aristotelés. Příznačná je v tomto ohledu tzv. Rétorika pro Alexandra dochovaná v korpusu Aristotelových textů: zde se slovo nalézá pouze v titulu, který je jako celý úvodní věnovací list pro Alexandra Makedonského jistě pozdějším falsem, zatímco vlastní poměrně rozsáhlý text, který je zřejmě upravenou učebnicí Anaximena z Lampsaku někdy z poloviny 4. století př. Kr., výraz nezná. Podobně Isokratés, který sice užívá slova rhétoreia, ovšem vesměs jako hanlivého označení pro řemeslné vyrábění řečí, od kterého se sám distancuje. K výskytu výrazu rhétoriké ve 4. století viz E. Schiappa, Protagoras and Logos: A Study in Greek Philosophy and Rhetoric, Columbia 2003², str. 219-225; k Isokratovi viz týž, The Beginnings, str. 156. 
ostatními, a jako taková má svůj specifický předmět, odlišný od jiných oborů; ${ }^{10}$ (2) tímto předmětem, který rétorika vytváří, nejsou věci, ale výhradně ,,reči““ (logoi); (3) tyto řeči nemají věcně informativní povahu (nebot' takové jsou logoi, které vycházejí z ostatních disciplín), omezují se tedy jen na nějakou jinou mimoinformativní, „,nevěcnou“ či ,pseudověcnou“ stránku: persuasivní působení; (4) z předchozí teze plyne, že rétorika se jako disciplína neorientuje na pravdu/jsoucí, ale pouze na ,přeludy“, „klamné obrazy“ jsoucího.

V pozadí těchto tvrzení pak stojí specifický názor na povahu řeči $(\log u)$, který ovšem předmětem rozhovoru mezi Gorgiou a Sókratem jako takový není. Sókratés předpokládá, že logos je něco zásadně odlišného od běžných věcí, co má ovšem schopnost tyto věci zobrazovat. ${ }^{11}$ O tom, že tato distinkce není pro předplatónské myšlení samozřejmá, svědčí přímo dochovaná přednáška historického Gorgii: zde má logos výslovně tělo (sóma), je tedy jednou z ,věcí“, byt' zvláštní. ${ }^{12}$ Teprve na základě jeho specifické reflektivní schopnosti lze u logu jasně rozlišit jeho „věcnou“, referenční funkci, kterou Platón fixuje jako poznání (epistémé): jeho pravdivost pak bude $\mathrm{v}$ dalších krocích Platónova myšlení garantována tím, že se bude ex definitione vztahovat k ,vpravdě jsoucímu“ (ontós on), k idejím. Od tohoto „věcného“ aspektu lze pak odlišit „nevěcnou“ funkci logu, stylistickou stránku v moderním smyslu, ${ }^{13}$ která neusiluje o to zobrazovat ,jsoucí“ a je vzhledem k podstatně referenční povaze řeči v zásadě problematická, ve vyostřené konfrontaci našeho dialogu je prrímo perverzí logu, tj. klamným obrazem, „přeludem“. Teprve na základě takto jasně vedených distinkcí, podložených ontologicky a epistemologicky, může Platón v Gorgiovi vytvořit teoretický rámec, do nějž zasadí rétoriku jako speciální disciplínu, a to disciplínu formální,

10 Explicitně stojí tato teze v jiných Platónových dialozích, viz Euthyd. 291e292a; Resp. 346a-c.

11 Tento předpoklad je v dialogu obsažen pouze implicitně, až známá pasáž o útěku k logu v Platónově Faidónu (99d-100a) připodobňuje logos výslovně k vodní hladině s její schopností reflexivně zobrazovat jiné věci.

12 Viz Gorgias, Hel., 8: „Řeč je mocným vládcem, který zcela nepatrným a zcela nepostižitelným tělem vykonává věci převeliké (doslova: maximálně bož-

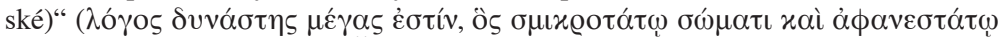

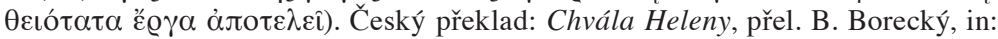
Tribuni výmluvnosti, vyd. B. Borecký, Praha 1974, str. 10.

13 Novým termínem pro tuto nevěcnou dimenzi logu se stává slovo lexis (mluva, styl), před Platónem (Apol. 17d3) a Isokratem (Or. V,27) nedoložené. 
zaměřenou na nevěcný aspekt řeči, totiž na její persuasivní působnost, která je jako taková odlišná od poznání, resp. přímo klamná. ${ }^{14}$

Novost Platónova ,zakladatelského aktu“ velmi jasně vynikne, pokud s výše analyzovanou argumentací srovnáme vzácná svědectví o rétorické teorii 5. století. Dochovaných relevantních pramenů z 5. století nemáme $\mathrm{k}$ dispozici mnoho, avšak ty, jimiž disponujeme, svědčí o tom, že reflexe tehdejší předplatónské (a v jistém smyslu předrétorické) výmluvnosti s takto jasnými demarkačními čarami nepracovala. Anonymní sbírka argumentů známá jako Dissoi logoi pochází nejspíše z konce 5. století př. Kr. ${ }^{15}$ Její osmý oddíl začíná následovně:

„Pokládám za vlastnost jednoho a téhož muže a jednoho a téhož umění, že dokáže rozmlouvat v krátkých otázkách a odpovědích, zná

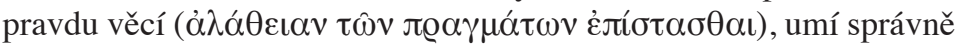
vést soudní proces i mluvit ve shromáždění, vyzná se v umění řečí a dovede poučit o prrirozenosti všech věcí, jak to s nimi je i jak vznikly

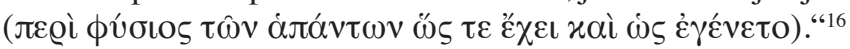

O něco málo níže je nárok na universální vědění znovu zopakován a zdůvodněn:

„Kdo ovládá umění řečí, bude umět mluvit o všech věcech správně. Každý, kdo má mluvit správně, musí mluvit o tom, co zná. Bude tak mít znalost všeho. Nebot' zná umění všech řečí, a všechny řeči se

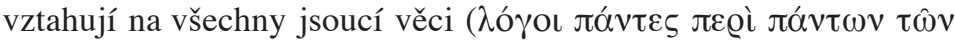

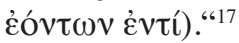

At' už hodnotíme výše uvedené proklamace jakkoli, nelze si nepovšimnout, že pro autora Dissoi logoi (či jeho zdroje) neplatí snad nic z toho, k čemu byl doveden platónský Gorgias během rozhovoru se Sókratem. Jeho ,jedno a totéž umění“ zř̀jmě nemá jen jeden specifický předmět, zcela odlišný od předmětů ostatních oborů, je naopak znalostí doslova

14 Ponecháváme zde stranou otázku takové řeči, která není poznáním ,vpravdě jsoucího“, přesto je ale pro lidský život důležitá tím, že dokáže odrážet ,nadjsoucí“ dobro či krásu, jak je Platón zkoumá především v dialozích Symposion a Faidros.

15 K dataci viz A. Becker - P. Scholz (vyd.), Dissoi Logoi-Zweierlei Ansichten, Berlin 2004, str. 16.

16 Diss. $\log .8,1$.

17 Tamt. 8,3-5 (znění posledních dvou slov je rekonstrukcí vydavatelů). 
„všech věcí“; toto umění není jen „formální“ disciplína, nebot' znalost logu zahrnuje i obsahovou znalost věcí; a tato znalost je znalostí zásadně pravdivou, nikoli „přeludem“. Text navíc jedním dechem spojuje témata, která jsme zvyklí vnímat jako specificky sofistická (logos, jeho politické a soudní uplatnění), nebo naopak jako typické cíle zkoumání presokratovských ,fysiologů“ či kosmologů (fysis, vznik universa věcí). Povšimněme si, že soudní a politická výmluvnost zde stojí vedle znalosti fysis všech věcí, avšak nikoli jako zvláštní cesta, po níž chce platónský Gorgias zajistit rétorice přednostní postavení maximalizací moci v polis. Spíše si můžeme domýšlet, že politická a soudní rétorika využívá a jakoby prodlužuje znalosti fysis do světa lidských institucí, jak to také uvidíme u pozdních presokratiků. Důležité přitom je, že kompilace $D i$ ssoi logoi není historiky pokládána za extravagantní myslitelský výboj, pravděpodobněji před sebou máme průměrné svědectví o dobovém intelektuálním standardu. ${ }^{18}$

Na pozadí, které nám Dissoi logoi nabízejí, je pak zajímavé číst výroky Sókratových partnerů a protivníků. Když Gorgias říká, že „rétor je schopen mluviti přede všemi a o všem“"19 a když se Hippias holedbá, jak „odpoví každému, kdo si přeje, na cokoli se táže “ ${ }^{20}$ nemusíme tato tvrzení nutně pokládat za plané vychloubání a důkaz jejich intelektuální či mravní naivity, ale též a spíše za svědectví o tom, že oni staří řečtí autoři, kterým dnes říkáme po Platónově vzoru „sofisté“, vycházeli ze zásadně odlišného modelu vědění, než který předkládá Sókratés a jeho žáci. Platónský Sókratés dokáže velmi přesvědčivě ,postavit rétoriku před soudní stolici etiky a ukázat její nicotnost“" právě a jen díky tomu, že podstatně promění podmínky, za nichž se jeho rozepře odehrává. Uzná-li se za platné, že každý druh vědění má svůj jeden specifický předmět, že vědění se vztahuje jen ke jsoucímu a že logos je něco odlišného od běžných věcí, co ale má schopnost tyto věci reprezentovat, pak se zájmy, témata a nároky Dissoi logoi (a patrně i historického Gorgii, Prótagory nebo Antifónta) musí jevit v nejlepším př́ípadě jako konfúzní. Tím pak

18 A. Becker a P. Scholz zdůrazňují didaktický cíl textu, který neměl za úkol formulovat nové teoretické náhledy, viz A. Becker - P. Scholz (vyd.), Dissoi Logoi Zweierlei Ansichten, str. 16, pozn. 14.

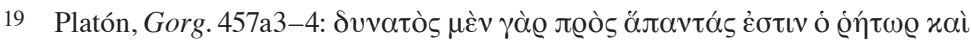

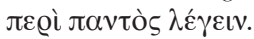

20 Týž, Hipp. mi.363d3-4. K těmto citacím lze připojit řadu dalších výtek chvástavosti a předstíraného vševědění na adresu sofistů jak u Platóna, tak u jiných (patrně též Sókratem ovlivněných) autorů, jakými jsou Xenofón (např. Memor. IV,4,8) nebo Isokratés (např. Or. XIII,2). 
narážíme na problém, kam uvedené autory v tradičních dějinách řecké filosofie zařadit, zda ještě $\mathrm{k}$ presokratovským fysiologům, anebo $\mathrm{k}$,sofistům“ coby předstupni attické ,filosofie logu“. ${ }^{21}$

Th. Cole věnoval velkou část své monografie rozboru nejstarších textů z konce 5. století, které standardně pokládáme za rétorické. ${ }^{22}$ Tyto převážně atticky psané dokumenty označuje jako „,vzorové a ukázkové texty“, které díky maximální sevřenosti a přísně symetrické stavbě obsahují při relativně malém rozsahu velké množství použitelných argumentačních postupů. Jak sbírka Dissoi logoi, tak páry schematizovaných řečí v Tetralogiích připisovaných Antifóntovi obsahují pozice pro et contra nikoli z důvodů nutně relativistického přesvědčení jejich autorů, ale jednoduše proto, že smyslem těchto textů bylo poskytnout maximum využitelných argumentů. Podobně obtížně jsou co do svého vyznění zařaditelné texty jako Gorgiova Helena a pseudo-Xenofóntova Athénská ústava, které vděčí za svou podobu nikoli snaze prezentovat autonomní literární dílo vyjadřující názor svého autora, nýbrž poskytnout co nejvíce argumentačních prvků pro další užití (v př́ípadě obou právě uvedených textů pro užití v soudní obhajobě, resp. v politické diskusi). Patrně i nejstarší dochované soudní řeči věnované konkrétním jednotlivým případům (Antifón, Lysiás, Andokidés, raný Isokratés) byly následně šr̂reny právě jako předlohy pro další tvorbu podobných textů. Smyslem existence těchto nejstarších rétorických textů proto není, aby byly čteny (např. pro požitek z autorovy virtuozity nebo pro poučení z jeho mimořádného vědění), ale aby byly dále zužitkovávány excerpováním, doplňováním konkrétního materiálu atp. ${ }^{23}$ Tato fáze je ovšem přísně vzato podle Coleho ne-rétorická či předrétorická, nebot' takto

21 Obecně lze říci, že i tradované rozdělení mezi presokratovské „př̌írodní filosofy“ a tzv. sofisty je do značné míry platónského původu. Už u Sókrata raných Platónových dialogů lze rozeznat tendenci odsouvat či ignorovat př́rodovědné zájmy jeho současníků a stavět je do protikladu ke kosmologům staršího stylu; k tomu viz F. Karfík, Hippias der Weise und Anaxagoras der Naturforscher, in: Graecolatina Pragensia, 16-17, 2000, str. 29-49. Použitelnost tohoto dělení pak ovšem výrazně klesá právě u těch textů, jejichž dochování platónsko-aristotelská tradice (včetně doxografické tradice theofrastovské) přímo neovlivnila, což je i př́ípad Dissoi logoi. Dalším příkladem jsou mj. spisy Corpus Hippocraticum, kterými se budeme podrobněji zabývat níže. (Různé hypotézy ohledně vzniku hippokratovské sbírky shrnuje S. Fischerová, Úvodní studie, in: Hippokratés, Vybrané spisy, I, vyd. H. Bartoš - S. Fischerová, Praha 2012, str. 117 n.)

22 Th. Cole, The Origins, str. 71-112.

23 Podobná intuice se objevila již ve starším bádání. E. Maass si všímá nedostatku specifického obsahu v Gorgiových textech a navrhuje je chápat jako „,vzorové 
pojaté texty neobsahují specificky rétorickou dimenzi, tj. teoretické vědění o tom, jakými formálními prostředky lze zajistit obsahům u toho kterého publika optimální přijetí. Tato rétorická metarovina je sama závislá na rozlišení čistě obsahového vědění, neutrálního vůči formálním možnostem $\log u$, a na škále možností vlastních separovanému řečovému médiu, které naopak slouží jako libovolně volitelné vehikulum pro ony obsahy - rétorika ve své klasické podobě se tak ukazuje jako doplněk, a nikoli jen protivník metafyzického vědění.

E. Schiappa se s Th. Colem rozchází především v otázce předpokládané absence jakékoli rétorické teorie v předplatónském období. Domnívá se, že samotná praxe transformování předlohových textů nedokáže vysvětlit některé důležité prvky protorétorických textů..$^{24}$ Oproti tomu navrhuje rozlišovat minimálně tři fáze formování rétoriky jako teorie. První fází jsou neteoretické texty, v nichž lze sice rekonstruovat jistá kompoziční pravidla, ta však nejsou nijak reflektována. Druhý krok Schiappa označuje jako nedeklarovanou teorii, kdy texty vykazují jisté formy metodologické reflexe (např. ustálenou základní terminologii), přesto však neobsahují formulovanou teorii, kterou autor jako takovou souhlasně nebo kriticky prezentuje. Třetí fáze již plně a výslovně kompoziční pravidla formuluje a diskutuje. Jako př́klad neteoretického textu mohou sloužit homérské eposy. Druhou fázi dobře ilustruje Gorgiova Chvála Heleny, která sice obsahuje výpovědi o povaze $\log u$, nikoli však explicitní pravidla konstrukce textu. Třetí fáze plně uvědomělé teorie se objevuje až ve čtvrtém století, v pokynech obsažených v Isokratových vzorových řečech, u Platóna, Alkidamanta a Aristotela. ${ }^{25}$ Schiappa však souhlasí s Colem v tom, že protorétorická výmluvnost mohla dosáhnout třetí, plně teoretizované fáze teprve tehdy, kdy byl Platónem (či sókratovským okruhem) vytvořen nový teoretický rámec, který zahrnoval výše nastíněné inovace na ontologické, epistemologické a terminologické rovině a $\mathrm{v}$ němž byla rétorika ustavena a definována jako hodnotově a obsahově neutrální techné řečového stylu, vposled však odkázaná na filosofii. ${ }^{26}$

formuláře", které bylo třeba doplňovat konkrétním obsahem: loci (E. Maass, Untersuchungen zur Geschichte der griechischen Prosa, in: Hermes, 22, 1887, str. 575 nn.).

24 Viz E. Schiappa, The Beginnings, str. 22 n.

25 Tamt., str. 109.

26 Jak je toto platónské vymezení problematické, ukazují celé pozdější dějiny rétoriky, v nichž se stále znovu vrací snaha redefinovat rétoriku obsahově, např. jako součást politické moudrosti. Už v Aristotelově Rétorice lze spatřit jisté pnutí mezi čistě formální definicí a snahou přiřadit rétorice určitá specifická témata. 
Jak svědectví Dissoi logoi, tak poukazy v Gorgiově diskusi se Sókratem ovšem naznačují, že mohlo existovat i jiné pojetí proto-rétoriky, které dokázalo poskytnout řecké výmluvnosti určitý teoretický rámec, a tedy i jistou metařečovou rovinu, aniž by bylo vázáno na představu jednoho speciálního umění vedle dalších a aniž by bylo závislé na modelu ryze věcného metafyzického vědění. Jako možnost se nabízí, že by i v rámci takovéhoto teoretického modelu bylo možné reflektovat a formulovat jasná pravidla pro konstrukci prozaického textu (Schiappova 3. fáze), byt' na odlišných ontologických a epistemologických předpokladech. Předmětem dalších zkoumání budou proto tzv. rétorizující spisy Corpus Hippocraticum, které dle našeho názoru jsou s to do otázky teoretických základů nejstarší rétoriky vnést alespoň zčásti nové světlo.

\section{2.}

Jako první poukázal na význam rétoricky formovaných textů dochovaných ve sbírce lékařských spisů Corpus Hippocraticum J. Jouanna. Ten v širší skupině textů určených primárně k ústnímu přednesu rozlišil v zásadě dvě podtřídy: didaktické kursy a řeči. ${ }^{27}$ Řeči či promluvy (discours) se od kurzů liší především kratším rozsahem (jejich přednes by neměl trvat déle než 30 minut), zdůrazněnými úvodními a závěrečnými pasážemi a užitím dekorativních kompozičních prvků, zejména symetrické výstavby větných úseků. Po obsahové stránce jsou tyto texty charakterizovány obecnější problematikou, která je činí zajímavými i pro nelékařské publikum..$^{28}$ V̌sechny tyto rysy pak Jouanna nalézá u čtveřice řečí De flatibus (O vzduchu a dechu), De arte (O umění), De vetere medicina (O starém lékařství) a De natura hominis (O přirozenosti člověka). Později Jouanna k této čtveřici volněji přiřadil i spis De morbo sacro (O svaté nemoci), který leží uprostřed mezi ,„rečí“ a „kursem““. ${ }^{29}$ Význam těchto spisů pro

27 Viz J. Jouanna, Rhétorique et médecine dans la collection hippocratique, in: Revue des études grecques, 97, 1984, str. 26-44. Mezi didaktické kursy (exposé didactique, cours) řadí Jouanna např. spis De aere, aquis et locis nebo propojená pojednání De genitura - De natura pueri - De morbis, IV.

28 Můžeme zde pominout nesnadnou otázku po místě těchto řečí v dobovém medicínském provozu; všeobecně se soudí, že sloužily popularizující propagaci lékařství.

29 Zvláštní pozice De morbo sacro je dána tím, že rozsahem a užitím stylistických figur se blíží řečem, ale nemá výrazně komponované prooimion ani závěr. K tomu viz Hippocrate, La maladie sacrée, vyd. J. Jouanna, Paris 2003, II, 3, str. X-xiii. 
dějiny rétoriky spočívá $\mathrm{v}$ tom, že jde o velmi dobře dochované texty, datované většinou interpretů ještě do 5 . století př. Kr., které tematicky rozšiřují převážně soudní zaměření nejstarších dochovaných protorétorických textů. ${ }^{30}$

Zatímco na důležitost rétoricky komponovaných hippokratovských spisů pro dějiny rétoriky upozornil v podstatě až právě J. Jouanna, ${ }^{31}$ již dřive byly a stále jsou intenzivně studovány historiky filosofie jako zajímavá svědectví recepce některých kosmologických a „sofistických“ nauk. H. Diels řadil spisy De flatibus a De morbo sacro mezi ohlasy učení Diogena z Apollónie, ${ }^{32} \mathrm{v}$ metodologických pojednáních De arte a De vetere medicina zase upoutával pozornost v nich rozvíjený model umění (techné). ${ }^{33}$ Avšak zrrídkakdy se hledala užší souvislost mezi rétorickou formou těchto spisů a jejich filosofickým obsahem. Nový pohled na Platónovu transformaci rétoriky nám však ukázal, že většina distinkcí, na kterých spočívá, nebyla pro starší autory závazná, stejně jako samotné rozlišení mezi filosofií a rétorikou jako dvěma jasně odlišenými obory. To nás vybízí $\mathrm{k}$ tomu uvažovat současnou přítomnost rétorické „formy“ a kosmologických nauk ve zvláštní skupině textů na konci 5. století (tedy před sókratovsko-platónským striktním rozlišením filosofie a rétoriky) nikoli jako náhodný souběh dvou izolovaných

30 J. Jouanna, vydavatel a komentátor všech těchto textů, je datuje následovně: De flatibus a De arte mezi roky 425 a 400 př. Kr. (Hippocrate, Des vents. De l'art, vyd. J. Jouanna, Paris 1988, V,1, str. 190 n.); De vetere medicina do doby 420-410 př. Kr. (Hippocrate, De l'ancienne médecine, vyd. J. Jouanna, Paris 1990, II, 1, str. 85); De natura hominis do let 410-400 př. Kr. (Hippocrate, De natura hominis, vyd. J. Jouanna, Berlin 1975, str. 59 nn.). Proti dataci do 5. stol. se postavil J. Redondo, který především na základě formálních kritérií umíst'uje spisy mezi léta 390-350 (J. Redondo, Sprachlich-stilistische Bemerkungen zu den rhetorisierenden Schriften des Hippokratischen Corpus, in: R. Wittern - P. Pellegrin (vyd.), Hippokratische Medizin und antike Philosophie, Hildesheim - Zürich - New York, 1996, str. 343-370, zvl. str. 366 nn.). Jeho názor ovšem zatím šířeji akceptován nebyl, viz E. M. Craik, The "Hippocratic" Corpus: Content and Context, London - New York 2015, str. 40, 102, 212, 285; W. Golder, Hippokrates und das Corpus Hippocraticum. Eine Einführung für Philologen und Mediziner, Würzburg 2007, str. 27, 56, 57, 59.

31 Dříve pouze F. Blass stručně zmínil některé z těchto řečí (F. Blass, Die attische Beredsamkeit, I, Von Gorgias bis zu Lysias, Leipzig 1887, str. 89 n.).

32 Viz H. Diels - W. Kranz, Die Fragmente der Vorsokratiker: griechisch und deutsch, II, Berlin, 1959, str. 66 nn.; A. Laks, Diogène d'Apollonie. Édition, traduction et commentaire des fragments et témoignages, Sankt Augustin 2008, str. 255 nn.

33 Např. Th. Gomperz, Die Apologie der Heilkunst, Wien 1890; F. Heinimann, Eine vorplatonische Theorie der $\tau \dot{\chi} \chi v \eta$, in: Museum Helveticum, 18, 1961, str. 105-130. 
intelektuálních tradic, nýbrž právě jako něco, co v této době spolu ještě může podstatně souviset.

Když J. Jouanna a J. Redondo studovali rétorický charakter těchto spisů, soustředili se především na jejich ozdobné stylistické a lexikální prvky, více či méně blízké těm z obou dochovaných Gorgiových řečí. Tím ovšem dochází $\mathrm{k}$ jistému zúžení v pojetí rétoričnosti, resp. $\mathrm{k}$ akceptování platonizujícího pojetí rétoriky coby jen „nevěcného“ stylu, vnějšně přistupujícího k separovanému obsahu. Poněkud stranou zde zůstal aspekt reflexivity, kdy promluva sama vyzdvihuje pravidla, podle nichž je konstruována. Naše zkoumání hippokratovských textů proto zahájíme u jiného z kratších spisů, kterému ani Jouanna ani Redondo nevěnovali svou pozornost. Jde o spisek De carnibus (O stavbě těla), který má $\mathrm{s}$ výše uvedenými rétorizujícími spisy řadu společných prvků. ${ }^{34}$ Vedle podobného rozsahu a tématu přesahujícího čistě medicínskou problematiku ho s původní Jouannovou čtveřicí spojuje také výrazné a rozsáhlé prooimion, naopak se odlišuje absencí dekorativních figur a propracovaných a symetricky komponovaných period. Text prooimia zní takto:

„V tom, o co se tato řeč opírá, budu užívat společně sdílených názorů, které pocházejí od jiných [autorů], kteří mně předcházeli, avšak také ode mě samotného. Kdo chce totiž vytvořit takovou řeč o lékařském umění, musí nutně postavit své názory na společném východisku

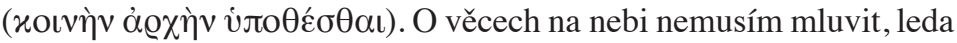
jen potud, nakolik jde o to ukázat u člověka a ostatních živých bytostí to, jak povstaly a vznikly, co je duše, co být zdráv a co být nemocen a co je v člověku dobro a zlo a proč umírá. Nyní tedy předložím své názory.“35

Citovaná pasáž dobře ilustruje charakteristické prvky, které Jouanna popisuje jako rys spisů určených primárně pro ústní komunikaci: poutání pozornosti na akt promluvy a osobu mluvčího, vnitřní odkazy a upozornění na strukturaci výkladu. Nadto je tu však nápadná reflexivní rovina,

34 Dostupná jsou následující komentovaná vydání spisu: Hippokrates, Über Entstehung und Aufbau des menschlichen Körpers, vyd. K. Deichgräber, Leipzig - Berlin 1935; Hippocrate, Des lieux dans l'homme. Du système des glandes. Des fistules. Des hémorrhö̈des. De la vision. Des chairs. De la dentition, vyd. R. Joly, Paris 1978, XIII, str. 181-206. Jak oba uvedení vydavatelé, tak E. M. Craik a W. Golder datují spisek mezi roky 450-400 př. Kr. (viz E. M. Craik, The „Hippocratic“ Corpus, str. 48; W. Golder, Hippokrates, str. 89).

35 De carn. 1. U poněkud neobratné první věty spisu zvažují komentátoři možné poškození textu. 
kdy autor sám explicitně formuluje pravidla, podle nichž bude svou promluvu komponovat: „Kdo chce totiž vytvořit takovou řeč o lékařském umění, musí nutně postavit své názory na společném východisku.“ Přitom se zde setkáváme s dvojznačností, kdy není snadné rozhodnout, zda autorovi jde jen o formální, řečově-argumentativní parametry (tedy o přesvědčivost), nebo o kritéria obsahová, tedy o „naturfilosofické“, teoretické základy medicíny. Předpokládejme, že podobně jasné rozlišení není pro autora De carnibus něčím tak samozřejmým, jak se to jeví čtenářům Platóna. Po výše uvedeném prooimiu totiž hned následuje výklad o „tak řečeném horkém“, které je „nesmrtelné a vše myslí, vidí, slyší a zná vše, jak to, co je, tak to, co má nastat“. ${ }^{36}$ Toto „horké“, které ze sebe aktivně vyděluje chladné a pevné, je pak principem konstituce a strukturace kosmu i tělesných anatomických struktur, kterým je věnována hlavní část spisu. Vidíme zde zvláštní souběh formální a obsahové stránky: to, co je počátkem či východiskem (arché) spisu, je také zároveň počátkem a principem strukturace universa. ${ }^{37} \mathrm{Z}$ terminologického hlediska pak prooimion obsahuje ještě jeden pozoruhodný reflexivní výraz: autor užívá ve spojení s arché tvaru slovesa hypotithesthai, které lze přeložit jako „vzít si za základ“, ,,podložit si“. Od tohoto slovesa je pak odvozeno substantivum hypothesis, které nás bude zajímat níže.

Takové spojení kosmologie s reflexí textové strukturace ovšem není zcela ojedinělé, nebot' ze stejné doby a zřejmě i ze stejného intelektuálního kontextu pochází dílo Diogena z Apollónie, ${ }^{38}$ jehož spis se sice jako

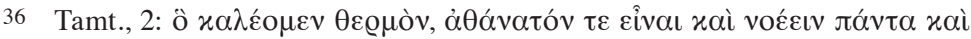

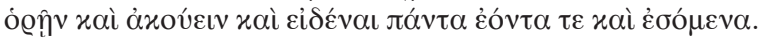

37 Pojem arché je základním termínem Aristotelova výkladu presokratiků, ačkoli v dochovaných zlomcích je terminologicky doložen pouze u Anaxagory (B 6 a B 12), a zde se nevztahuje primárně k očekávané ,pralátce“, nýbrž k tomu stavu kosmu, kdy mysl započíná kruhovým pohybem jeho strukturaci. Viz Z. Kratochvíl, Anaxagorás, Červený Kostelec 2014, str. 64. Výrazným rysem Anaxagorova myšlení (a psaní) je však linearita: to, co bylo „na počátku“ kosmu, stálo patrně i na počátku knihy (k tomu viz tamt., str. 50-56). Podobný souběh obsahového a formálního (textově-strukturálního) ohledu nalézá C. A. Huffmann v užití slova arché ve Filoaově zlomku B 6 (DK 44); C. A. Huffmann, Philolaus of Croton. Pythagorean and Presocratic, Cambridge 1993, str. 85-91; A. Šíma, Svět vymezený a neomezený, Červený Kostelec 2012, str. $101 \mathrm{n}$.

38 Také výše citované pasáže z De carnibus zařadil H. Diels mezi ohlasy Diogenových myšlenek. Na druhou stranu je ovšem dílo samotného Diogena pokládáno za značně eklektické. Proto je dle našeho názoru užitečnější místo jednosměrných působení předpokládat spíše jakousi širší bázi společně sdílených témat a postu-

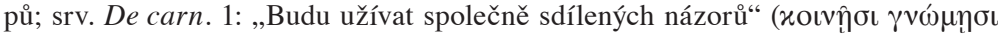

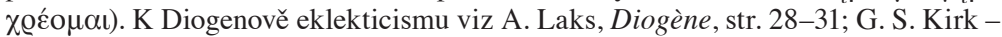


celek nedochoval, ale citace, uchované Simplikiem v jeho komentáři k Aristotelově Fyzice, lze seřadit s velkou spolehlivostí tak, jak za sebou následovaly v originální knize. Na počátku stojí zlomek B1 (DK 64): „Zdá se mi, že na začátku každé řeči je třeba poskytnout nesporné vý-

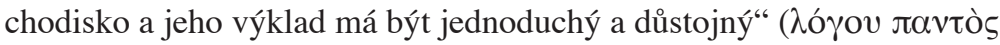

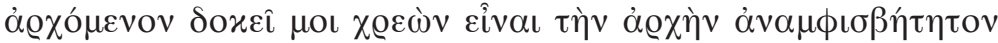

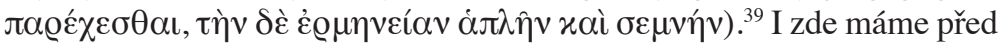
sebou explicitní reflexi o tom, jak má být logos stavěn a jaké má mít vlastnosti. Druhým rysem, jímž se Diogenova kniha shodovala s De carnibus, je podobná lineární stavba: to, co je na počátku „ve jsoucím“, je také na počátku $\log u$, výkladu ${ }^{40}$ Další dochované zlomky se týkají povahy jsoucího obecně a její jednotné či spojující dimenze (B2). Poté je této dimenzi přiřčeno myšlení (noésis; B3) a je ztotožněna se vzduchem (aér; B4). V dalších zlomcích je vzduchu přiřčena podobná vše řídící a vševědoucí role, jakou v De carnibus hraje „horké“. Zde je navíc explicitně zdůrazněno božství tohoto principu, které bylo pro řeckého čtenáře a posluchače už implikováno v pojmech nesmrtelnosti a věčnosti:

„Zdá se mi, že to, co má myšlení, je vzduch, takto lidmi nazývaný (ó àj@ $x \alpha \lambda \circ u ́ \mu \varepsilon v o \varsigma)$, a že ten je všechny řídí jako kormidelník a ovládá i všechny věci. Domnívám se totiž, že právě toto je bohem, že jeho působnost zasahuje na všechna místa, pořádá všechny věci a je ve všem přítomné. A neexistuje jediná věc, která by na něm neměla nějaký podíl.“(B5)

„Ale zdá se mi být jasné, že je i velké, mocné, věčné, nesmrtelné a že

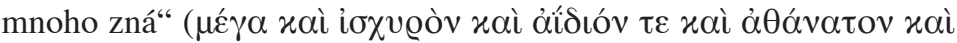

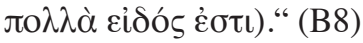

J. E. Raven - M. Schofield, Předsókratovštífilosofové, přel. F. Karfík - P. Kolev - T. Vítek, Praha 2004, str. 560 nn. (odtud přejímáme i níže citované překlady Diogena).

39 Diogenés z Apollónie, DK 64 B 1.

40 Už roku 1933 si K. Deichgräber při svém zkoumání hymnických prvků v próze pozdních presokratiků (de facto Anaxagory a jeho následovatelů) povšiml reflexivní povahy prooimia Diogena z Apollónie s poznámkou, že by zasluhovalo větší pozornost, nebot' příliš nezapadá do tradičního obrazu dějin rétoriky (K. Deichgräber, Hymnische Elemente in der philosophischen Prosa der Vorsokratiker, in: Philologus, 88, 1933, str. 354, pozn. 15). A. Laks zdůrazňuje formální zaměření zlomku DK 64 B 1, který explicitně mluví o počátku a výkladu řeči, nikoli o počátku kosmu (viz A. Laks, Diogène, str. 57-59). Avšak ani zde nelze předpokládat tak silné rozestoupení formy a obsahu, které se objevilo až se sókratovsko-platónskou filosofií. 
Strukturní podobnost Diogena a De carnibus, podtržená navíc uvedenými lexikálními shodami, by nám však neměla zakrývat odlišnost v konkrétní identifikaci strukturujícího principu (,vzduch“ vs. „horké“). To př́iliš neladí s očekáváním, že naukově závislý lékařský spis nebude měnit principiální kosmologická rozhodnutí své filosofické předlohy. Nelze tedy vyloučit, že specifická literární forma souvisí s určitým obecnějším typem kosmologie, nikoli př́mo s naukou Diogena z Apollónie. ${ }^{41}$

Věrnější vůči Diogenově nauce je spíše řeč De flatibus. Svým rozsahem i základním rozvrhem je v mnohém analogická spisku De carnibus: zatímco zde se vyšlo od kosmologického principu, aby z něho byla vyvozena stavba lidského těla, v De flatibus se z obecných principů buduje universální patologie či aitiologie nemocí. Jejím hlavním činitelem je vzduch, který je nejen hlavní příčinou nemocí, ${ }^{42}$ ale též hymnicky velebeným vládcem světa:

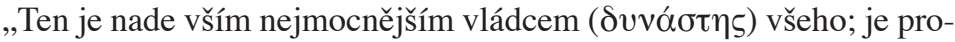

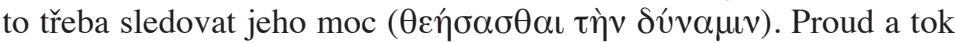
vzduchu je vítr, a jakmile hodně vzduchu utvoří silný proud, stromy jsou silou tohoto vanutí vyvraceny z kořenů, moře se vzdouvá a i nesmírně velké nákladní lodi jsou rozprášeny. Taková je jeho moc nad těmito věcmi. Přitom je zraku nezjevný, zjevuje se ale uvažování (

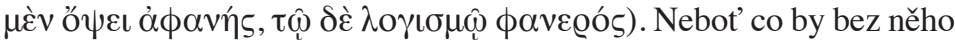
mohlo vzniknout a čemu není prrítomen? A k čemu se nepřidává?‘“43

Oproti předchozím pasážím zde nemáme výslovný poukaz na vševědoucnost a božství vzduchu, můžeme se však domnívat, že oboje je

41 De carnibus má zde zřejmě blíže k Archelaovi, u nějž jsme prakticky odkázáni jen na sekundární reference. Z nich však můžeme soudit na to, že pokládal kosmologický proces za jakési diferencování, při němž se od sebe odlišuje pohyblivé teplé a pasivní chladné. Toto strukturování si Archelaos představoval snad jako pulzaci či otřásání vycházející z mysli („,horkého“), pro niž užíval tvary slovesa tarassó (soudě podle předpokládaných ohlasů této nauky v De carn. 2; 3 a Papyru Derveni, sl. IX). K tomu viz G. Rechenauer, Archelaos aus Athen, in: D. Bremer - H. Flashar G. Rechenauer (vyd.), Philosophie der Antike, I, Frühgriechische Philosophie, 2, Basel 2013, str. 797-810.

42 Tímto patologickým činitelem je vzduch uzavřený v různých tělesných dutinách, označený výrazem fysa, jejž lze nejlépe přelžit slovem plyn. V české hippo-

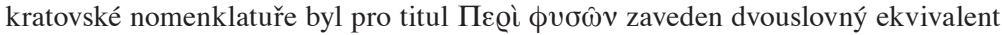
O vzduchu a dechu, srv. Hippokratés, Vybrané spisy, I, str. 539 nn.; týž, Vybrané spisy, II, vyd. H. Bartoš - S. Fischerová, Praha 2018, str. 599 nn.

43 De flat. 3. 
implikováno jeho vládnoucím postavením a všudypřítomností. Na rozdíl od De carnibus jsou věty této přednášky budovány více periodicky a s využitím tzv. gorgiovských figur (antithese, isokólon, parison, homoioteleuton). Stejně jako v předchozích textech je tu prítomný prvek explicitní reflexe výstavby textu, který se nyní ovšem nenalézá v proоimiu (poměrně dlouhý úvod je věnován chvále lékařství), nýbrž na závěr řeči, v epilogu:

„A to [sc. plyn] jsem jako skutečnou prríčinu nemocí přivedl k důkazu, nebot' jsem přeci slíbil objasnit př́činu nemocí. Ukázal jsem, jak

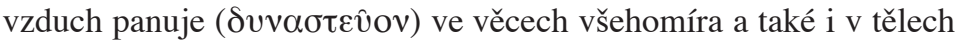
živých bytostí. Svůj výklad jsem přivedl ke známým nemocem a ob-

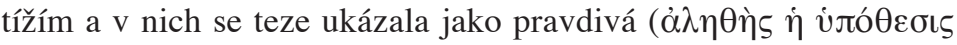

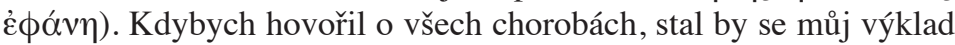
sice delší, nikoli však jistější ani přesvědčivějšíi.“44

Náš komentář De flatibus musíme omezit na dvě témata. Dochovaným Gorgiovým přednáškám Chvála Heleny a Obrana Palaméda se text blíží nejen užitím gorgiovských figur, ale též řadou paralelních obratů a slovních konstrukcí, a to zejména ohledně první z obou řečí. ${ }^{45}$ Tato skutečnost vyvolává otázku ohledně vztahu mezi Gorgiou a anonymním autorem De flatibus. Jako nejpravděpodobnější se samozřejmě jeví domněnka, že neznámý autor De flatibus měl při komponování textu před očima (nebo v živé paměti) Gorgiovy řeči. Tento předpoklad nicméně neobjasňuje všechny podobnosti. Nejpozoruhodnější paralela se totiž nalézá mezi popisem moci vzduchu v hippokratovském spisku a moci logu u Gorgii, na nějž jsme už výše narazili: „Řeč je mocným vládcem, který zcela nepatrným a zcela nepostižitelným tělem vykonává věci převeliké“ (doslova nanejvýš božské, theiotata). ${ }^{46}$

Nejenže i vzduch v De flatibus je opakovaně charakterizován názvy vládce či moci (dynastés, dynamis), je zde také nápadná shoda v tom, jak Gorgias tuto moc charakterizuje. Jeho logos činí maličkým a nezjevným tělem „božské věci“, zatímco očím nepatrný vzduch hippokratovského

\footnotetext{
44 Tamt., 15.

45 Viz Hippocrate, Des vents; De l'art, str. $22 \mathrm{nn}$.

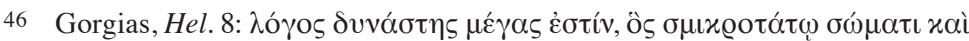

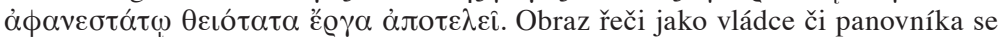
v ranější rétorice objeví i jinde, byt' už bez jakékoli „ontologické“ explikace, viz Isokratés, Or. III,9; Anaximenés, Ars rhet. 1421, 1425.
} 
autora se stává druhotně viditelný na věcech, které „ovládá“, jako jsou např. větrem vyvracené stromy či bouří zmítané lodě. ${ }^{47}$ Pokud autor De flatibus skutečně pouze použil jako vzorový text Chválu Heleny a přenášel Gorgiovu charakteristiku logu na diogenovský vzduch, pak je překvapivé, že druhotné užití v závislém textu působí plastičtěji než jeho údajná původní předloha (nehledě na masivnější užití výrazů odkazujících k dynamis a příbuzným výrazům). Skutečnost, že se gorgiovský popis $\log u$ minimálně na lexikální rovině velmi přibližuje popisům vědoucího strukturujícího činitele kosmu u autorů blízkých Diogenovi, by neměla být podceněna jen jako pouze formální, jazyková shoda. Zvláštní kompatibilita mezi gorgiovskou a diogenovskou dimenzí De flatibus může spolu s reflexivními elementy v De carnibus a u Diogena odkazovat ke společné terminologické a naukové základně, ve které by ještě v 5. století „formálně-rétorické“ a „obsahově-kosmologické“ aspekty $\mathrm{Z}$ velké části spadaly vjedno.

V epilogu De flatibus jsme viděli rovněž užití výrazu hypothesis (přeloženo jako „teze“, doslova ,podklad“), substantiva odvozeného ze slovesa hypotithémi, na jehož mediální formu hypothesthai jsme narazili v prologu De carnibus. V obou těchto pasážích je hypothesis (či aktivita označovaná př́buzným slovesem) spojena s logem, toto spojení naznačuje už poměrně stabilní, téměř terminologické užití. Aby řeč mohla vypovídat a působit, je třeba jí dát správný ,ppodklad“, téma (subjekt, „syžet"), a potud je výraz srozumitelný už na své etymologické rovině. V De flatibus je přítomný ovšem i druhý, protichůdný moment toho, co hypothesis znamená. Samotný ,podklad“ řeči, téma, nemůže být bez $\log u$, řeči, v níž se ukáže, zda a jak je ,podklad“ realizován, zda se vyjeví jako pravdivý. Hypothesis tak není pouhé „téma“, které by bylo jen předložené k libovolnému zpracování, ale zároveň též aktivní rozvíjení tématu, jeho dynamická prezentace na rovinách, které téma samo původně neobsahovalo a které ho činí akceptovatelným. Díky této podvojné, cirkulární povaze spojuje hypothesis jak formální aspekt (provedení tématu), tak obsahový aspekt (téma), aniž by předpokládala separování na čistě formální moment a na obsah existující mimo své provedení. To lze vysledovat o něco později u Isokrata, který užívá výrazu hypothesis v podobném smyslu jako hippokratovští autoři. ${ }^{48}$

47 Zde připomeňme Anaxagorův zlomek B 21a: ,jevy jsou spatřením nezjevné-

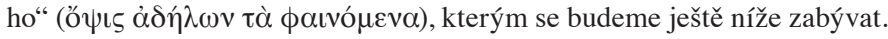

48 Isokratés užívá od počátku 4. století termín hypothesis už jako stabilizovaný reflexivní („literárně-teoretický“) pojem při svých radách a komentářích ohledně 
Tím se dostáváme k dalšímu z rétorizujících spisů, k traktátu De vetere medicina. $\mathrm{V}$ jeho polemických pasážích nalézáme výraz hypothesis hned několikrát. Autor se obrací proti svým blíže nespecifikovaným protivníkům těmito úvodními slovy:

„Lidé, kteří se chopili úkolu hovořit nebo psát o lékařství a kteří si

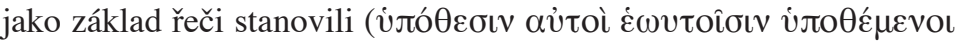
$\tau \hat{\omega}(\lambda o ́ \gamma(\omega)$ teplo, chlad, vlhko, sucho nebo něco jiného, co se jim

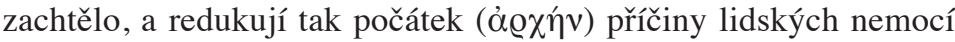

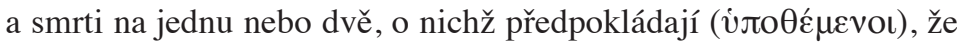
jsou tytéž ve všech př́ípadech, se v mnohém z toho, co říkají, dopouštějí chyb.“49

Na konci téže vstupní kapitoly se polemika ještě jednou vrací a s ní i výše užité výrazy. Zajímavé je další pokračování argumentace, v němž je tvorba hypothesí pokládána za základní postup typicky presokratovského „fysiologického“ zkoumání:

„Proto se nedomnívám, že lékařské umění potřebuje nový základ

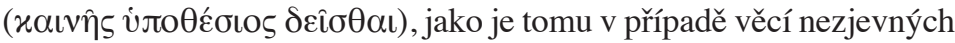

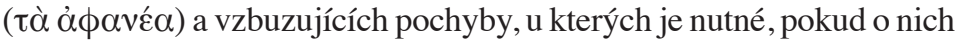

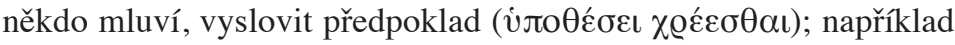
o tom, co je na nebi nebo pod zemí. Kdyby měl někdo mluvit o takových věcech nebo poznávat, jaké jsou, nebylo by jasné ani jemu samému, jakožto mluvčímu, ani posluchačům, zdali je to pravda nebo ne." ${ }^{\text {50 }}$

Také v De vetere medicina je hypothesis výslovně spojena s aktivitou řeči, avšak ještě explicitněji než v předchozích textech je tu dána do souvislosti s některým z ,prvkü“ (horko, chlad, vlhko...), a to v kontextu

řečnické tvorby. Také zde se význam pohybuje v rozmezí téma řeči a provedení či rozvinutí tématu (řečí). Viz např. Isokratés, Or. X,1: „Někteří lidé si vyberou neobvyklý a podivný námět (hypothesin) a velmi si považují, dokáži-li o něm přijatelně promluvit.“ XI,9: „Aby se nezdálo, že dělám to, co je nejsnadnější, totiž útočit na to už řečené, pokusím se krátce promluvit na to samé téma (hypothesin).“ XI,49: „Jestliže mě poslechneš, nebudeš napříště tvořit špatné řeči (hypotheseis).“ (dále srv. též Or. XII,35; 96; 108; 175; Or. XV,276 či slovesně Or. III,14). V obecnějším smyslu mluví Isokratés též o hypothesi jako základu určitého skutku nebo celého života, který se v jeho průběhu rozvíjí a řídí jej (viz Epist. VI,9; Or. VI,90).

49 De vetere medicina $(=V M)$ 1,1, in: Hippokratés, Vybrané spisy, I, str. 365 (přel. J. Daneš).

$50 \quad V M 1,3$. 
fysiologického zkoumání. Řeč využívající a rozvíjející hypothesis do-

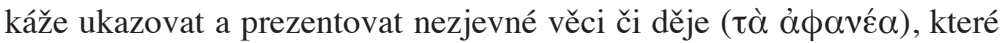
jsou dále charakterizovány typickou formulí jako ,věci na nebi nebo pod

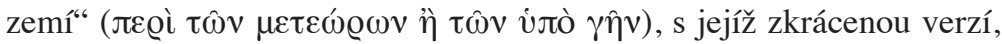

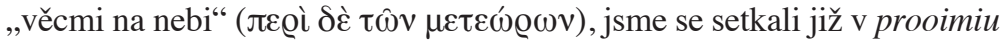
De carnibus. Tato částečná shoda s naposled zmíněným spisem nám může pomoci přesně vyhodnotit polemický tón De vetere medicina, který bývá někdy vykládán jako projev radikálního empirismu odmítajícího všechny „metafyzické hypotézy“. Hypothesis v námi probraných textech ovšem není hypotézou v moderním smyslu (tedy teoretickým předpokladem, který má být experimentálně testován), ale spíše východiskem narativní syntézy, která dokáže založit to, co má být v řeči prezentováno. ${ }^{51}$ Tato interpretace snad dokáže být více práva dvojznačnostem, s nimiž musí anachronické čtení dotyčného spisu zápolit. Nejenže se autorova pozice neobejde bez teoretických ,neempirických“ komponent. ${ }^{52}$ Jak se výslovně říká ve výše uvedeném druhém úryvku, medicína se podle něj obejde bez nové hypothesis ${ }^{53}$ což pak ovšem neznamená, že by měla být bez žádné, resp. že nemá nějakou ,starou“ hypothesis, kterou není třeba nahrazovat.

Pochopíme-li hypothesis jako základ shrnující narace, pak je jasnější, proč autor vykládá obsáhle vznik životosprávného lékařství jako součást civilizačního procesu, při němž jsou už od jeho počátků objevovány různé úpravy pokrmů za účelem snazší stravitelnosti. Potud i autor De vetere medicina pracuje s nějakou hypothesis, i když se nevrací na počátek strukturace kosmu, ale pouze na „hypotetický“ počátek lidské civilizace. V tom je jeho pozice srovnatelná s autorem De carnibus, který se snaží kosmologické východisko redukovat („,O věcech na nebi nemusím

51 W. D. Smith, Analytical and Catalogue Structure in the Corpus Hippocraticum, in: F. Lassere - Ph. Mudry (vyd.), Formes de pensée dans la Collection hippocratique, Genève 1983, str. 277-284 zřejmě jako první postřehl, že celá polemika z úvodu De vetere medicina se primárně týká adekvátní literární formy, nikoli empirické versus metafyzické metodologie v lékařství (metodologické problémy byly v předplatónském myšlení 5. století př. Kr. ještě formulovány spíše „materiálně“, tedy mj. jako problém literární formy vhodné pro uchovávání a předávání vědění). M. J. Shiefsky ve svém obsáhlém komentáři Smithovu intepretaci bohužel nezohledňuje (viz M. J. Shiefsky, Hippocrates. On Ancient Medicine, Leiden - Boston 2005).

52 Např. pluralita dynameis obsažená v přírodních objektech, tělech a jejich částech a št'ávách, viz VM 19; 23-24.

53 Čteme s částí rukopisné tradice a většinou moderních editorů a překladatelů

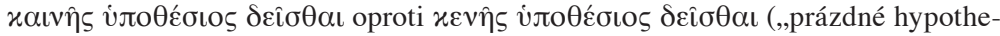
sis“), viz Hippocrate, De l'ancienne médecine, vyd. J. Jouanna, Paris 1990, str. 119 a $157 \mathrm{n}$. 
mluvit, leda jen potud, nakolik jde o to ukázat u člověka...“). Oproti tomu v De vetere medicina je toto východisko transformováno do vyprávění o rostoucích možnostech lékařství v průběhu civilizačního vývoje. ${ }^{54}$ I když je pak na jiném místě hypothesis odmítnuta paušálně, ${ }^{55}$ může tak autor činit pouze díky svému (neodůvodněnému) mínění, že jím postulované dynameis $\mathrm{v}$ prrírodních substancích jsou zásadně jiné kvality než kosmos strukturující „horké“ či „,vzduch“ jeho kolegů a že proces asimilace potravy lze zcela separovat od kosmického dějství. Zatímco tedy zakládající výklad De carnibus a De flatibus vychází od nyní přímo neověřitelných počátků, zkouší autor De vetere medicina založit souhrnnou naraci o lékařském umění na aktuální zkušenosti každého jednotlivce (na reakci vlastního organismu na různé typy pokrmů a nápojů). Od této přímé zkušenosti zpětně rekonstruuje dietetickou medicínu jako vůdčí sílu (nyní již také přímo nepřístupného) civilizačního procesu. ${ }^{56}$

Jak ovšem posoudit užití výrazů hypotithesthai a hypothesis ve výše komentovaných pasážích spisů De carnibus, De flatibus a De vetere medicina a shody tohoto úzu s Isokratovým reflektováním literární tvorby? První vysvětlení, které se nabízí, je, že jejich autoři prošli nějakou formou stylistického školení, nejspíše tak, že při psaní měli před sebou některý $\mathrm{z}$,modelových textư“. Pro tuto variantu by svědčil i fakt, že zmíněná reflexivní terminologie se objevuje v úvodech (De carnibus), závěrech (De flatibus) nebo polemických pasážích (De vetere medicina), tedy v partiích, na něž se protorétorické technai často omezovaly. ${ }^{57}$ Proti tomu však mluví jednak chronologie nám dochovaných textů ${ }^{58}$ jednak to, že

54 Nevyřčený zde zůstává původ oněch dynameis a skutečnost, že spolu mohou interagovat, mísit se a vzájemně modifikovat své působení (srv. zlomek B 2 z Diogena z Apollónie).

55 Viz $V M, 2,3$ : „Z téhož důvodu nepotřebuje lékařství žádný předpoklad“ ( $x \alpha \grave{~}$

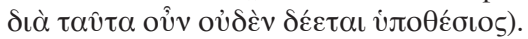

56 Nepochybným záměrem autora De vetere medicina je emancipovat lékařství od určité podoby presokratovské filosofie, z našeho pohledu se však spíše jedná o spor uvnitř dvou podob presokratovského myšlení, o přesun těžiště zájmu $\mathrm{k}$,lidskému kosmu“. Odlišného názoru je M. J. Schiefsky, podle něhož spis vzešel z imanentně lékařské problematiky (Hippocrates, On Ancient Medicine, vyd. a přel. M. J. Schiefsky, Leiden - Boston 2005).

57 Srv. G. Kennedy, The Earliest Rhetorical Handbooks, in: American Journal of Philology, 80, 1959, str. 169-178.

58 Podle konsensuální datace jsou dotyčné hippokratovské texty o několik dekád starší než relevantní Isokratovy řeči, které lze datovat s poměrnou přesností: Or. XI (Busiris) 391-385 př. Kr.; Or. X (Helena) cca 370 př. Kr.; Or. III (Nicocles) 372-365 př. Kr.; Or. XV (Antidosis) 354-353 př. Kr.; Or. XII (Panathenaicus) 342-339 př. Kr. 
spojení „literárně-formálního“ termínu hypothesis s kosmologickým principem - což je bod, v němž se všechny tři jinak naukově odlišné spisky shodují - působí velmi organicky, zatímco více formální Isokratův úzus se zdá být spîše odvozený. Počítat tedy budeme raději s opačnou možností, totiž že výrazy hypothesis a hypotithesthai patřily k myšlenkovému a literárnímu instrumentariu určité fáze řecké kosmologie.

\section{3.}

Je známo, že autoři Diogenés z Apollónie a Archelaos v řadě naukových prvků i literárních postupů navazují na Anaxagoru..$^{59}$ Jeho filosofie se v polovině 5 . století př. Kr. stala vlivným intelektuálním proudem, vyzařujícím do různých oblastí kultury. Tematické, terminologické a literárně-technické shody, které tvoří takový společný rámec, lze nazvat „,anaxagorovskou koiné" druhé poloviny 5 . století ${ }^{60}$ Aniž bychom zde museli otevírat všechny nejisté otázky rekonstrukce Anaxagorova učení, shrňme stručně hlavní rysy anaxagorovské vědy a její literární prezentace.

Naše znalosti Anaxagory se opírají jen částečně o zlomky vlastního textu, zbytek známe pouze z referencí, přičemž dochované př́mé citace pocházejí pochopitelně z těch pasáží, které přednostně zajímaly jejich pozdější uchovavatele, což v našem případě většinou znamená pozdně

(datace podle Isocrates, I, přel. D. Mirhady - Y. L. Too, Austin 2000, str. 10 n.). Proti Redondovu pokusu datovat rétorizující hippokratovské spisy do první poloviny 4. století (Sprachlich-stilistische Bemerkungen, str. 366) lze namítnout i to, že filosofický styl blízký tomu Diogenovu či Archelaovu byl kolem roku 370 už překonaný a nevykazoval by takovou atraktivitu. Isokratés by spíše sám musel vycházet ze stejných předrétorických terminologických konvencí, jaké dokládají rétorizující hippokratikové.

59 Za jednu z nejnápadnějších spojnic můžeme pokládat roli kosmické mysli a způsob, jakým se o ní mluví. Srv. Anaxagorás zl. DK 59 B 12: „Ostatní věci mají podíl na všem ostatním, mysl je však bezmezná, je samovládná a nesmísila se s žádnou věcí, nýbrž je jediná sama o sobě... Je totiž nejjemnější a nejčistší ze všech věcí, podržuje veškerou znalost o veškerenstvu a je nejsilnější.“ Výše citované pasáže z De carnibus, De flatibus a z Diogena, zl. B 1 (srv. též Papyrus Derveni, sl. XVI nebo De morb. sacr., 16) se jeví jako víceméně manýristické přiblížení anaxagorovského kosmologického jazyka tradičnímu religióznímu slovníku.

60 Že nejde o konstrukci moderního bádání, dosvědčují i Dissoi logoi, 6 zmi-

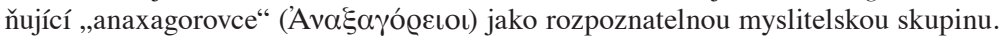
K Anaxagorově vlivu na soudobé intelektuální prostředí viz G. Rechenauer, Anaxagoras, in: D. Bremer - H. Flashar - G. Rechenauer (vyd.), Philosophie der Antike, I, Frühgriechische Philosophie, 2, str. 782 nn.; Z. Kratochvíl, Anaxagorás, str. 210 nn. 
antické filosofy. Anaxagorova nauka byla trefně charakterizována jako „teorie všeho“61 a dochované zprávy o obsahu jeho „knihy“ tento dojem jakési svérázné encyklopedičnosti jen potvrzují. ${ }^{62}$ Moderními kategoriemi lze tento obsah anachronicky popsat jako sled zkoumání zabývajících se ontologií, kosmologií a astronomií, meteorologií, geologií, hydrologií a celou řadou témat biologických. Archelaos pak ve svém spisu dovedl toto encyklopedické pořadí ještě dále k teorii o vzniku kultury. ${ }^{63}$ Soudě podle dochovaných zlomků byla řada $\mathrm{z}$ těchto témat probírána poměrně podrobně, a to se týká i takových problémů, které dnes neřadíme do filosofie, ale do některé ze speciálních věd. ${ }^{64}$

I přes fragmentární povahu dochovaných textů můžeme soudit, že tvářnost anaxagorovské naukové prózy určovaly dva hlavní, na první pohled protikladné prvky: jednak hymnické pasáže, vztahující se k vševědoucímu a vše pronikajícímu principu strukturace světa, využívající k zdůraznění anafor, antitezí a opakování, a na druhé straně velmi věcná, střízlivá próza výkladových pasáží. ${ }^{65}$ To odpovídá ostatně i zásadní dualitě v pojetí světa těchto myslitelů, kde na jedné, privilegované straně stojí kosmická mysl, pronikající světem a formující jej, na druhé straně je zbylý svět stále více či méně zanořený do nerozlišitelnosti (,,směsi všeho se vším“), z níž se rozlišitelná jsoucna a struktury našeho světa působením světové mysli postupně vydělují (aniž by kdy byly vyděleny úplně) ${ }^{66}$

61 Viz P. Curd, Anaxagoras and the Theory of Everything, in: P. Curd - D. W. Graham (vyd.), The Oxford Handbook of Presocratic Philosophy, Oxford 2008, str. 230-249.

62 Srv. Hippolytovo resumé $D K 59$ A 42; český překlad Z. Kratochvíl, in: týž, Anaxagorás, str. 256-261.

63 Viz testimonium $D K 60$ A4 rovněž z Hippolyta (český překlad Z. Kratochvíl, in: týž, Anaxagorás, str. 262-265). Archelaovou naukou o vzniku kulturních institucí se detailně zabývá G. Betegh, Archelaus on Cosmogony and the Origins of Social Institutions, in: Oxford Studies in Ancient Philosophy, 51, 2016, str. 1-40. Sociální a kulturní instituce zřejmě zajímaly už i Anaxagoru (viz zl. B 21b).

64 Napřr. rozsáhlý Diogenův popis lidské žilní soustavy dochovaný Aristotelem (DK 64 B 6).

65 Srv. G. F. Nieddu, Neue Wissensformen, Kommunikationstechniken und schriftlichen Ausdrucksformen in Griechenland im sechsten und fünften Jahrhundert v. Chr.: Einige Bemerkungen, in: W. Kullmann - J. Althoff (vyd.), Vermittlung und Tradierung von Wissen in der griechischen Kultur, Tübingen 1993, str. 161 nn. K povaze anaxagorovské prózy srv. též K. Deichgräber, Hymnische Elemente, passim; Z. Kratochvíl, Anaxagorás, str. $50 \mathrm{nn}$.

66 Spíše jen terminologický rozdíl mezi Anaxagorou a jeho pokračovateli spočívá v tom, že Anaxagorova mysl může strukturovat a řídit svět proto, že se s ničím 
Ačkoli naprostá většina dochovaných citací z Anaxagory a Diogena pochází od Simplikia a ačkoli reflektuje z obou presokratiků hlavně to, co odpovídá platónsko-aristotelskému pojetí filosofie, tedy především motiv kosmické mysli, můžeme si díky dochovaným hippokratovským přednáškám De carnibus a De flatibus učinit jistou představu o funkčním propojení výše zmíněné „hymnické“ a encyklopedické komponenty a celkové povaze anaxagorovské prózy. Obě svým způsobem reprezentují cíleně redukované podoby anaxagorovského diskursu, kde jsou počáteční kosmogeneze i šîre a bohatství vznikající fysis co možná minimalizovány ve prospěch antropologického zaměření. ${ }^{67}$ De carnibus začíná téměř rovnou velebícím popisem universální působnosti vševědoucího „takřečeného horkého“ (kap. 2), v De flatibus analogické hymnické pasáži oslavující moc vzduchu, větru a plynu předchází ještě krátká chvála lékařského umění (kap. 1). Ve zbývajícím výkladu podávají oba spisky zhuštěné poučení o lidském těle; v případě De carnibus o vzniku jeho tvrdých a měkkých částí působením horka, ${ }^{68}$ De flatibus se věnuje všeobecné patologii. Přitom ona kosmologická vstupní hypothesis nadále funguje jako integrující činitel dalších výkladů. Prakticky každá nová tematická položka (v De flatibus každý typ chorob či obtíží, v De carnibus každá

ze světa nemísí (srv. zlomky DK 59 B 11; 12), zatímco Archelaos, a zejména Diogenés ztotožňují mysl s jednou z kosmických komponent (horko, vzduch) a připisují jí stejnou roli proto, že se naopak se vším mísí a tvoří universální základ kosmu, čímž jejich dílo nabývá oproti Anaxagorovi místy monistické ladění. K otázce materiálnosti Anaxagorovy kosmické mysli srv. P. Curd, Anaxagoras of Clazomenae, Toronto 2007, str. $200 \mathrm{n}$.

67 V 5. století stále převládá ústní forma šíření textů, vůči níž má psaný text druhotnou roli předlohy pro ústní přednes nebo jeho záznamu. To s sebou nese větší plasticitu intelektuálních statků, než je tomu v primárně skripturálních kulturách. Literární „dílo“ je zde mnohem více spojeno se situací, v níž je komunikováno, a je tudíž více otevřené různým změnám, abreviacím, rozšiřování atp. Texty De flatibus a De carnibus si proto můžeme představit jako lékařskému zájmu přizpůsobené výtahy z anaxagorovského modelu vědy. K tomu srv. R. Thomas, Performance and Written Publication in Herodotus and the Sophistic Generation, in: W. Kullmann J. Althoff (vyd.), Vermittlung und Tradierung von Wissen, str. 225-243; táž, Prose Performance Texts. Epideixis and Written Publication in the Late Fifth and Fourth Centuries, in: H. Yunis (vyd.), Written Texts and the Rise of Literate Culture in Ancient Greece, Cambridge - New York 2003, str. 162-188.

68 De carn. 3 podrobně popisuje, jak se působením horka vlhká a stále velmi smíšená země diferencuje na mastné a vazké složky; dalším působením horka se sušší mastné části ,vypalujî“ na kosti, více vlhké vazké části se plně nevypálí, a dají tak vznik dutým měkkým tkáním a orgánům. Z dochovaných textových dokladů anaxagorovců tomuto popisu nejlépe odpovídá referát o Archelaově zoogonii u Hyppolyta (A 4), srv. G. Rechenauer, Archelaos aus Athen, str. 803 n. 
anatomická struktura ve svém vzniku), jak se také odráží v novodobém členění textů na kapitoly a paragrafy, obsahuje výslovné vztažení obsahu k „horkému“" nebo ke vzduchu (plynu, dechu) v jejich působnosti. Přitom bývá tento odkaz často zdůrazňován jak svým postavením ve větě a ve větším tematickém celku, tak užitím různých jazykových prostředků, především opakováním ustálených obratů ${ }^{69}$ Zde jsou funkce a podvojný význam slova hypothesis dobře patrné. Na jedné straně hraje kosmologický strukturující prvek v obou řečech roli organizačního prostředku, prričemž jednotlivá dílčí témata jsou nástrojem pro propojení obou řečí. Zároveň však specializovaný výklad následující po exaltovaných hymnických pasážích slouží k tomu, aby tuto výsostnou funkci kosmologických principů naopak zdůvodnil a diskursivně obhájil. Autoři obou námi probíraných spisků se uchylují k poměrně složitým důkazním postupům, díky nimž se působnost na první pohled nezřetelných kosmologických činitelů stává patrnější a výklad sám nabývá víceúrovňový charakter, který překračuje pouhou deskripci a otvírá prostor kauzální interpretaci. Terminologicky jsou opory těchto důkazů fixovány jako znaky či indicie (sémeia, tekméria). ${ }^{70}$

Doslovně podobné důkazní postupy ve velkém množství nalézáme, jak známo, i v dochovaných nejstarších řečnických textech, bylo by tedy opět možné se domnívat, že mohly do hippokratovských spisů přejít odtud. ${ }^{71} \mathrm{~V}$ prrípadě „rétorického“ De flatibus se tento předpoklad

69 Jako př́íklad takového konstruování uved’me v originále několik po sobě jdoucích začátků kapitol či menších tematických jednotek z De flatibus (členění uvnitř

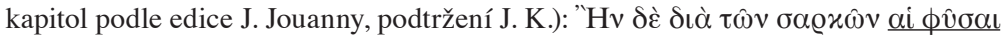

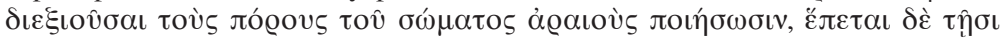

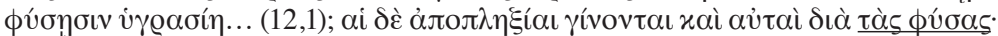

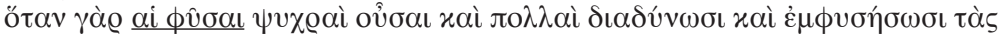

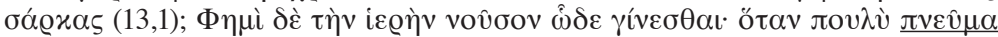

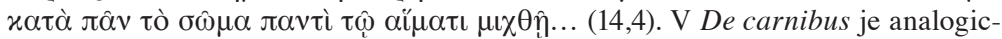
ká strukturace ještě patrnější díky užívání stereotypizovaných formulací, viz např. De carn. 8,1; 9,1; 9,2; 10,1.

70 De flat. 12,2; De carn. 4,3; 15,3; 19,7. Občas autor vybízí i k jednoduchým pokusům, které mají potvrdit jeho tezi: De carn. 8,2. Viz též De arte, 5,3.

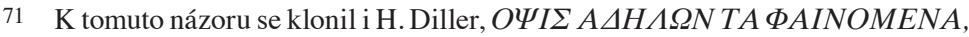
in: Hermes, 67, 1932, str. 14-42, který ve své důležité studii rozlišil analogickou a sémiotickou metodu rané řecké vědy a filosofie. Druhý postup však pokládal za převzatý z rétoriky. K podobnosti výše uvedených pasáží s obdobnými důkazními postupy u attických řečníků viz např. Isokratés, Or. III,7; XXI,11. Specificky protorétorický původ má však zřejmě především tzv. pravděpodobnostní úsudek (eikos), viz Platón, Phaedr. 267a; 273b, zatímco uvedené sémiotické postupy byly standardní metodickou a argumentativní výstrojí právě již u anaxagorovců. 
jeví opět velmi plausibilně, avšak u textu De carnibus, jenž je v tradičním slova smyslu nerétorický, bez dekorativních figur, ztrácí na své přesvědčivosti - nehledě na to, že podobný ,sémiotický“ postup patřil prokazatelně už k argumentační výstroji Diogena z Apollónie. ${ }^{72}$ Jasně reflektovaný a uvědomělý sémiotický postup tedy spîše náležel k vlastní metodě konstruování „diskursu“ anaxagorových pokračovatelů. Tomu by pak odpovídal význam často diskutovaného Anaxagorova zlomku

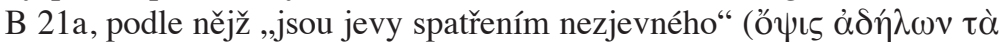
$\phi \alpha ı v o ́ \mu \varepsilon v \alpha)$. Přestože nelze zcela vyloučit možnost, že Anaxagoras není jeho vlastním autorem, a přestože nelze určit přesný kontext, v němž ho mohl zformulovat, ${ }^{73}$ můžeme si pomocí obou dochovaných hippokratovských přednášek, konsensuálně pokládaných za blízké Diogenovi (či Archelaovi), udělat určitější obraz o tom, jak tato zásada fungovala přinejmenším v části anaxagorovské recepce. Nejenže je působnost $(d y$ namis) obtížně sledovatelného vzduchu či „horkého“ patrná až na jejich efektech a stopách na jiných, snáze pozorovatelných věcech. Ve svém celku musí být z jednotlivých znamení a analogických poukazů zviditelněna teprve až v kosmologicko-encyklopedickém narativu (v podvojném, cirkulárním smyslu slova hypothesis), jehož utváření a strukturace byly podstatnou součástí pozdně presokratovské myslitelské praxe.

4.

Kosmologický motiv světové mysli a jeho funkci coby „literárně-organizačního“ principu jsme sledovali v De flatibus a De carnibus, jeho polemický ohlas pak v polemických pasážích De vetere medicina. Tím se však důležitá témata rétorizujících hippokratovských spisů zdaleka nevyčerpávají. V závěru našich zkoumání se budeme blíže věnovat

72 Viz začátek Diogenova zlomku B 4: „Kromě toho jsou pro tyto věci ještě další důležitá znamení. Lidé i ostatní živočichové žijí díky vzduchu..."

73 Zlomek mohl v tomto znění pocházet od Démokrita (Sextus, který fragment dochoval, pokračuje: ,jak říká Anaxagorás, za což ho Démokritos chválí“, viz Adversus mathematicos, VII,140). Další možností je, že jde o obecnější úsloví. Ani v otázce, co je oním nezjevným, které má být pomocí zjevných fenoménů zkoumáno, nejsou interpreti jednotní: D. Sider soudí, že se jedná primárně o Anaxagorova „semena“ před jejich akumulováním náležité velikosti (D. Sider, The Fragments of Anaxagoras, Sankt Augustin 2005, str. 165 n.). P. Curd pokládá za ono nezjevné činnost kosmické mysli v jejím působení na kosmologické i biologické rovině (P. Curd, Anaxagoras of Clazomenae, str. 75 n.). 
„metodologickým“ spiskům De arte a De vetere medicina, v nichž se motiv kosmické mysli jako takové výslovně nevyskytuje, přesto však nejsou bez vztahu ke dříve probraným explicitně anaxagorovským textům.

Ve výše citovaném prooimiu De carnibus se mluvilo o „lékařském umění", koncept umění (techné) hrál důležitou roli i v Sókratově debatě s Gorgiou ve stejnojmenném Platónově dialogu. Už dříve bylo v bádání poukázáno na to, že v metodologických úvahách některých hippokratiků je předpokládán poměrně homogenní model techné, který slouží jako teoretický standard, podle nějž je potom lékařství jako speciální prríklad umění poměřováno (tak je tomu především v řeči De arte). Prvky tohoto modelu se pak vedle hippokratovských spisů objevují v řadě Platónových dialogů a $\mathrm{v}$ textech, které tradičně definujeme jako sofistické či rétorické (Dissoi logoi, Isokratés) ${ }^{74} \mathrm{~F}$. Heinimann, který se pokusil tento model rekonstruovat, předpokládal, že společné doktrinární prvky v platónských dialozích a hippokratovských rétorizujících spisech musejí odkazovat k určité „sofistické teorii techne“ jako svému pozadí ${ }^{75}$ Umění jako takové je podle těchto textů definováno několika podstatnými obecnými rysy, mezi něž patří např. jeho prospěšnost pro lidstvo ${ }^{76}$ nebo jeho učitelnost. Dále sem podle Heinimanna patří ten rys, jehož užila platónská argumentace, aby doložila netechnický charakter nově zkonstruované rétoriky: existence jednoho specifického předmětu, k němuž se má každé odborné vědění vztahovat. Srovnáme-li v tomto bodě sókratovsko-platónské formulace s jejich paralelami v metodologických hippokratovských spisech, můžeme si vedle překvapivých shod povšimnout i určitého, nikoli nevýznamného rozdílu. Platón stejně jako hippokratovské spisy často charakterizuje umění jako působnost (dynamis), avšak podstatný důraz klade na finální aspekt umění, totiž na to, že ke každému umění náleží jeho specifický výkon (ergon),

74 Ve výrazu techné, který sloužil též jako označení vzorových řečí i pozdějších systematických učebnic rétoriky, se na konci 5. století soustředí zkušenost stálého růstu lidského vědění a možností jednání; k tomu viz Chr. Meier, Ein antikes Äquivalent des Fortschrittsgedankens: Das „Können-Bewußtsein“ des 5. Jahrhunderts v. Chr., in: týž, Die Entstehung des Politischen bei den Griechen, Frankfurt a. M. 1983, str. 435-499.

75 F. Heinimann, Eine vorplatonische Theorie der $\tau \dot{\varepsilon} \chi v \eta$, in: Museum Helveticum, 1961, 18, str. 106-130. Srv. též S. Fischerová, Technicita hippokratovského lékařství a její meze, in: S. Fischerová - A. Beran (vyd.), Medicína mezi jedinečným a univerzálním, Červený Kostelec 2012, str. 61-85, autorka zde rekonstruuje obecně hippokratovský pojem umění.

76 Tu obšírně zdůrazňuje i prolog De flatibus, viz De flat. 1. 
jímž je definováno a jehož žádným jiným uměním nelze dosáhnout. ${ }^{77}$ Předplatónský model oproti tomu zdůrazňuje více dovedností, postupů a cest, které dopomáhají jednotlivci k šířeji pojatému prospěchu. Když hippokratovské metodologické spisy mluví o dynamis lékařství, nesnaží se uvést jeden jediný cíl lékařského vědění a konání, nýbrž příznačně vždy uvádějí větší počet stavů nebo dějů, které lékař díky své odbornosti může nebo má znát či způsobovat. ${ }^{78}$ Sókratovsko-platónský model mnohem více vyčleňuje speciální odborné vědění ze souvislosti vědění jako celku, proto také může dospět k pojetí techné jako eticky neutrálního vědění, zatímco starší předsókratovští autoři včetně hippokratiků s takto ostrým rozlišením etického a faktuálního vědění nepracují. Podle dochovaných textů byl v pátém století za nejpatrnější znak techné pokládán spíše rozdíl mezi laiky a odborníky, resp. samotná existence úspěšných profesionálních odborníků, ${ }^{79}$ než definovaný vztah vědění a dovedností k jednomu specifickému cíli, předmětu.

Nárok na všeobjímající a méně diferencované vědění „sofistů“, které znají texty Sókratových žáků už jen jako cíl efektního vyvracení nebo ironického zesměšňování, a které naopak Dissoi logoi dokládají jako neproblematické východisko, se nám nyní může ukázat ve svém původním kontextu. Vševědění či vědění mnoha věcí jsme výše opakovaně sledovali jako typický atribut anaxagorovské kosmické mysli. At' je tomu s její materiální povahou jakkoli, je tato mysl zároveň kosmu imanentní, je jeho strukturující složkou a primárním vnitřním hybatelem, a její všeobsáhlé vědění tedy nespočívá v tom, že by stála „mimo“ svět jako jeho distancovaný pozorovatel. Transformování motivů kosmické

77 Viz instruktivní pasáž z Resp. 346a-c, kde Sókratés dokazuje, že lékař svým uměním výhradně léčí, ale nevydělává peníze. Ty získává nikoli lékařstvím, ale dalším přidruženým uměním, ,námezdnictvím“.

78 Viz De arte, 3,2: „Úplně zbavovat nemocné utrpení, zeslabovat intenzitu nemocí a nezasahovat v př́ípadě, kdy nemoc již získala naprostou převahu." Srv. Epidemiae, I,5, kde rovněž chybí zdánlivě samozřejmý odkaz na „zdraví“ jako vlastní cíl lékařství. Stručně řečeno: předplatónský (,,sofistický“) model předkládá prostředky a cesty, jak úspěšně působit např. jako lékař, ale nemluví (nedovede mluvit) o jednom cíli. Díky takovému reformulování pojmu techné může Sókratés ve výše probíraném dialogu upř́it technický status gorgiovské rétorice. Více viz J. Kube, TEXNH und APETH. Sophistisches und platonisches Tugendwissen, Berlin 1969, str. 57 nn. a 108 nn.

79 Viz VM 4. Rozdíl mezi laiky a odborníky (v klasickém Řecku institučně fundovaný relativně slabě) spočíval v poslední instanci na reálném rozdílu ve vědění. K tomu srv. níže, pozn. 84, a J. Klouda, Semeia und Tekmeria im 5. Jahrhundert v. Chr.: Ein Beitrag zur Geschichte der ältesten griechischen Semiotik und Argumentationstechnik, in: Listy filologické, 2016, 3-4, str. 275-299. 
mysli a jejího vědění v problematice techné, včetně její diskursivní, řečové stránky pak zajímavě reprezentuje krátká přednáška De arte (Пe@ì $\tau \dot{\varepsilon} \chi v \eta \varsigma) .{ }^{80}$ Ta je rozsahem, gorgiovskými figurami i některými speciálními výrazy velmi podobná De flatibus, na první pohled v ní ale chybí výraznější stopy diogenovské kosmologie. Místo toho zde nalézáme metodologické úvahy na poměrně vysokém stupni abstrakce; hlavním tématem spisku je bránit lékařství proti těm, kteří mu status umění (techné) upírají. Argumentace, jíž autor brání technickou povahu lékařství, nám pak poskytuje zřetelnější obraz právě o onom standardu technického vědění a konání, o který se vedl spor. $V$ textu pak skutečně můžeme identifikovat prolínání dvou rovin: jednak té konkrétněji zaměřené na lékařství, jednak roviny výpovědí o umění jako takovém. ${ }^{81}$

Druhý z obou hlavních argumentačních bloků (kap.9-12) začíná rozdělením onemocnění na dvě třídy, zjevné a nezjevné nemoci ${ }^{82}$ Zatímco zjevná onemocnění nemají představovat pro lékařské posouzení závažnější problém, nezjevné nemoci sídlící uvnitř těla v obšírně vypočítávaných dutých tkáních a ústrojích ${ }^{83}$ představují výzvu, na níž se prokáže, zda si lékařství označení „umění“ opravdu zaslouží. Na konci své řeči autor nastíní řadu indicií i umělých diagnostických postupů, díky nimž lékař dokáže získat informace o těchto skrytých nemocech ${ }^{84}$ Mezi obojím se nalézá vysvětlení, jehož je závěrečný výčet diagnostických postupů vlastně jen konkretizující exemplifikací. To, co činí nezjevné nemoci přístupné ,zraku mysli“, je úvaha, kalkul: „Nebot' co unikne zraku očí, je podrobeno zraku mysli. ... Když lékař nemohl původ bolesti zrakem spatřit ani sluchem vypátrat, sledoval jej úvahou." ${ }^{85}$

80 Vedle zmíněných komentovaných vydání Th. Gomperze a J. Jouanny viz novější rozbory, které podávají P. Cordes, Iatros. Das Bild des Arztes in der griechischen Literatur von Homer bis Aristoteles, Stuttgart 1994, str. 101-137 a J. Klouda, O umění, in: Hippokratés, Vybrané spisy, I, str. 291-343 (zde obsažený překlad užíváme v citacích De arte; řecký text uvádíme podle J. Jouanny).

81 Viz De arte 1,$1 ; 2 ; 9,1$.

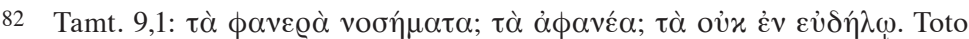
atypické rozdělení nemocí v celé hippokratovské sbírce připomíná už jen přednáška De flat. 1 („,ovšem ta nejnezjevnější a nejtěžší onemocnění jsou posuzována spíše pomocí teoretického náhledu“"). Najde se též v Hérodotově referátu o egyptské medicíně, Hist. II,84.

83 Viz De arte, 10.

84 Tamt., 12.

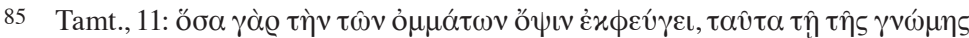

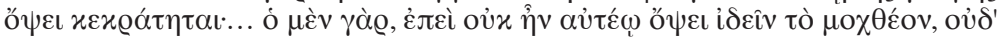

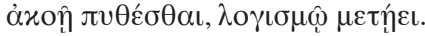


Substantivum logismos označující úvahu či kalkulaci nebo původní sloveso logizesthai, od nějž bylo substantivum odvozeno, se objeví v De arte ještě dvakrát, pokaždé však v úzkém sepětí s konceptem umění. V jedné z př́edešlých kapitol se říká, že „lékaří ... zvažují poměr přítomných stavů $\mathrm{k}$ podobným stavům $\mathrm{v}$ minulosti “ ${ }^{86}$ Popisovaný proces se týká schopnosti prognózy, které autor připisuje zásadní hodnotu s ohledem na status obhajované technicity lékařství: „Lékařské umění se naopak zřretelně ukazuje ... v onom ,kvůli čemu' a v jeho předvídání a v tom je a vždy bude jeho podstata. “" ${ }^{87}$ Podstata umění spočívá na př́íčinném provázání skutečnosti („,kvůli čemu“, k němuž se níže ještě vrátíme), jež umožňuje logismem vykonávané předvídání, prognózu. Avšak logismos stojí i za schopností získat vědění o nezjevných nemocech skrytých uvnitř těla, jejî̌z oslavou řeč graduje. Umění tak díky logismu překonává parciální „ted’ a tady“, přivádí nezjevné ke zjevu. Pečlivá interpretace textu De arte nám tak nabízí další podstatný atribut umění, který F. Heinimann ve své studii opominul (snad proto, že kolidoval s předpokladem jednoho specifického cíle každého oboru) a který „,sofistickou teorii umění" staví do blízkosti kosmologií anaxagorovského typu. ${ }^{88}$ Připomeňme, že logismos byl v De flatibus prostředek, jímž bylo

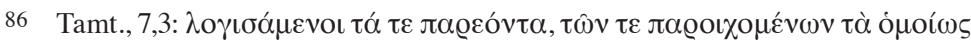

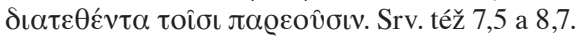

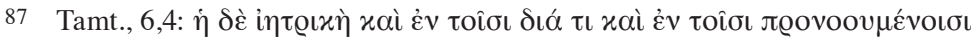

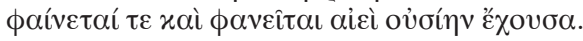

88 Viz J. Kube, TEXNH und APETH, str. 76-88. Schopnost logu zpřítomnit nepřítomné (zpravidla minulé nebo budoucí) je na přelomu 5. a 4. století důležitým prvkem specifického kognitivního étosu řeckého osvícenství. Sebevědomé proklamace této schopnosti tvořily součást protorétorické a starší rétorické „,ideologie“, viz např.: Isokratés, Or. IV,141: „Nezjevné se nejrychleji pozná ze zjevného“; též Or. VI,59; I,34; II,35. Andokidés, Or. III,2: „Je třeba využít toho, co se odehrálo dříve jako znamení vypovídajícího o budoucím.“ Hypereidés, zl. 196 Jensen: „To, co je nezjevné, musí studující hledat prostřednictvím znamení a pravděpodobností.“ Antifón, zl. 8 Radermacher: „Antifón v Techné říká, že o př́ítomném se přesvědčuje prostřednictvím znamení, o budoucím indiciemi." Srv. též Thukydidés, Hist. I,1; 22; 133. Opakovaného výskytu podobných hesel u attických autorů konce 5. a začátku 4. stol. si povšiml Klement Alexandrijský, resp. anthologista, z kterého Klement čerpal, Strom. VI,18,1 (česky: Klement Alexandrijský, Stromata, VI, přel. M. Šedina, Praha 2011, str. 189). Význam slova techné jako názvu vzorových protorétorických textů může se schopností zpřítomňovat nepř́ítomné souviset tak, že cílem soudní rétoriky je rekonstruovat minulý děj, úkolem politické výmluvnosti zpřítomnit budoucí možnost (srv. Aristotelés, Rhet. III,17,1418a2 nn.). Zpřítomnění neprrítomného (techné v prvním smyslu) pak předpokládá schopnost konstruovat prozaický text (techné v druhém smyslu). Na přelomu 5. a 4. století pak nalézáme pojmenování „umění řečí“ (logón techné), které naznačuje už jistou institucionalizaci a jednotu 
možné sledovat moc (málo patrného) vzduchu na více zjevných věcech; $\mathrm{s}$ uměním ho spojuje i další z rétorizujících spisů, přednáška De vetere medicina.$^{89}$

Přestože v De arte postrádáme explicitní přítomnost vševědoucí materiální kosmické mysli prostupující universem, je zde rozvíjený koncept umění bližší presokratovským kosmologiím více, než se může na první pohled zdát. První tematický blok (kap. 3-8) je věnován vyvrácení častých námitek vznášených proti lékařství. Autor se vyrovnává s tvrzením, že mnozí lidé, kteří se po zavolání lékaře uzdraví, se uzdraví náhodou, a nikoli působením umění, případně že se mnozí uzdraví sami bez lékařského umění (kap. 4-6). Argumentace, jíž autor De arte čelí těmto výtkám, působí na moderního čtenáře dosti rozporuplně. Řeč tvrdí, že pokud se někdo uzdraví náhodou sám, není to nic proti technické povaze lékařství, jelikož takový člověk ,náhodou narazil na lékařské umění“.90 Jelikož skoro vše v př́rodě (věci i činnosti) má nějaký kauzální účinek na zdraví, je možné, že se i laik náhodou s úspěchem vystaví takovým působením, která by mu předepsal i lékař. O něco později autor prohlašuje, že samovolné procesy přísně vzato neexistují, vše je kauzálně propojeno: „U všeho, co vzniká, můžeme nalézt něco, kvůli čemu to vzniklo, a vzhledem k tomuto kvůli čemu samovolnost neexistuje jinak než jen jako jméno." ${ }^{91}$ Pokud nemocný náhodou vstoupí do kauzálních procesů, které vedou ke zlepšení jeho stavu, a sám cítí, že mu prospívají,

„sofistické“ výmluvnosti (viz Anonymus Iamblichi, 2; Dissoi logoi, 8; Xenofón, Memor. I,2,31, srv. též De arte 2,2).

89 K De flatibus viz výše, podle VM 12 je lékařské umění „schopno se dopra-

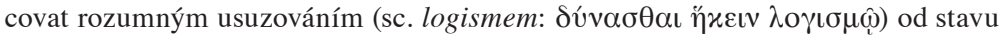
naprosté nevědomosti k něčemu, co je takřka shodné s jistotou“. K tomu srv. J. Daneš, O starém lékařství, in: Hippokratés, Vybrané spisy, I, str. 401 n.; Hippocrates, On Ancient Medicine, str. 222. Prostřednictvím logismu charakterizuje poznání i Gorgias ve Chvále Heleny (viz Hel. 2).

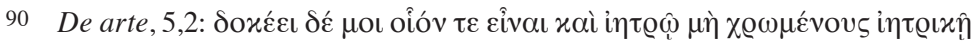
$\pi \varepsilon \varrho \iota \tau \cup \chi \varepsilon \hat{\imath}$.

91 Tamt., 6,4. Historikové řecké filosofie dosud plně nedocenili fakt, že právě $\mathrm{v}$ rétorizujících hippokratovských spisech nalézáme proklamace kauzálního principu v takové explicitnosti jako nikde jinde u presokratovských autorů; vedle pojednávané pasáže z De arte, 6 viz též De nat. hom. 13; De flat. 1; 2; 15; De morb. sacr., 2; 18 (a rétorizujícím spisům blízký, jen podstatně rozsáhlejší De victu, I,15), přičemž De flatibus a De morbo sacro můžeme pokládat př́ímo za monografie věnované obecné, resp. speciální aitiologii. Zejména k posledně jmenovanému spisu viz P. Hobza, Příčinnost a přirozenost v hippokratovských spisech, in: Aither, 15, 2016, str. 4-29. 
je již při díle umění. Podle toho lékařské umění nespočívá primárně v záměrném vědění (jako soubor osvojených poznatků a praktik), ale v tom, že tělo je zapojeno do kauzálních vztahů provazujících kosmos a dokáže odlišit ty účinky, které mu prospívají. V tomto smyslu může autor De arte mluvit o umění jako o něčem, co existuje i mimo intencionalitu vědoucích „subjektů“. Tento prvek v konceptu umění De arte byl hodnocen jako pouhý úskok sofistického advokáta či jako účelová konstrukce, která měla z lékařského umění samého vyloučit reálné, a tedy vždy potenciálně chybující lékaře.$^{92}$ Aniž bychom museli zpochybnit apologetickou tendenci spisku, je možné se ptát na pozadí, o něž se taková argumentace opírala a z něhož čerpala svou přesvědčivost. Vezmeme-li v úvahu literární i tematickou blízkost k ostatním rétorizujícím spisům, pak je na místě chápat lékařské vědění „samo o sobě“ podle vzoru kosmické mysli prostupující světem, a teprve druhotně jako parciálně vykonávané lidskými osobami. ${ }^{93}$ Odtud lze lépe porozumět také kategorickému požadavku na bezchybnost umění, dobře pochopitelnému z nauky o vševědoucí kosmické mysli, avšak dosti spornému vzhledem k reálné míře úspěchů hippokratovských lékařŭ.$^{94}$

92 Viz W. Müri, Griechische Studien. Ausgewählte wort- und sachgeschichtliche Forschungen zur Antike, Basel 1976, str. 57 n.; P. Cordes, Iatros, str. 124.

93 Postulovaná universalita kauzálního propojení (,u všeho, co vzniká, můžeme nalézt něco, kvůli čemu to vzniklo“) odpovídá tomu, jakou roli hraje u Diogena „,vzduch“. Ten tvoří poslední, vším prostupující rovinu reality, díky níž mohou různé (z této roviny povstalé) věci na sebe navzájem působit. Přitom je ,vzduch“ vlastním nositelem inteligence a vzhledem k rozumné uspořádanosti kosmu je pak důležité, že řada příčinných působení může prospívat zdraví a živá by tost to cítí i bez lékařského umění. Srv. Diogenés, zl. B 2: „Všechny jsoucí věci se proměňují z téhož a jsou totéž

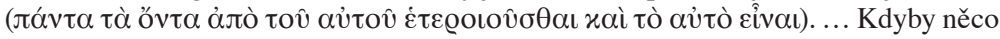
z nich bylo rozdílné jedno od druhého... nebylo by žádným způsobem možné, aby se věci navzájem mísily, ani aby jedna prospívala nebo škodila druhé...“ Diogenovský „takřečený vzduch“ jako médium mysli i kauzality je moderně řečeno subjektem i objektem vědění.

94 Viz De arte, 9,4; 10,1 (o nutnosti úspěšné léčby v případě „,zjevných onemocnění“). O reálné úspěšnosti tehdejších lékařů si můžeme udělat jistou představu na základě kazuistik v knihách Epidemiı́, viz J. Černá, Epidemie, I, in: Hippokratés, Vybrané spisy, II, str. 454. O vztahu kosmické a lidské mysli u anaxagorovských autorů jsme zpraveni pouze stručně, byt' s jistotou víme, že tento vztah byl tematizován. Viz Anaxagoras, zl. B12; Diogenés, zl. B4 a B5. 


\section{Závěr}

Hodnota svědectví rétorizujících hippokratovských spisů spočívá v tom, že nám ukazují pouze relativní platnost rozlišování mezi iónskou kosmologií a tzv. sofistikou. Analýza těchto spisů nás přivádí k nahlédnutí, že ještě před radikálním oddělením obsahu a formy, nauky o věcech a nauky o mimověcné dimenzi řeči (,stylu“, lexis) existovala jistá část anaxagorovské kosmologické tradice a recepce právě jako zřetelně diskursivní praktika, jako reflektovaná konstrukce orálních a skripturálních textů. V rámci tohoto proudu byla ustavena pravidla a formulována základní terminologie, která překračovala pouhou praxi kopírování a upravování vzorových textů, na níž podle Thomase Coleho spočívala předplatónská protorétorika. Lineární povaha anaxagorovské kosmologie a role mysli jako svět pronikajícího, ovládajícího a strukturujícího činitele mohly prvním „proto-rétorům“ sloužit jako vhodný teoretický model k chápání logu, implikující rovněž praktické zásady konstrukce textů. Tento rámec přesto nebyl pouze formální, odkazoval naopak k podstatným komponentám kosmické reality a tvořil základ pro podstatné rysy předplatónské techné jako maximalizovaného vědění usnadňujícího svým nositelům orientaci ve světě. Všechny tyto prvky, které mohly být rodící se rétorikou využity pro její sebedefinování, tvoří díky svému anaxagorovskému původu poměrně homogenní „teoretické pole“, množinu více či méně kompatibilních naukových, terminologických a argumentačně-technických možností.

Teprve na tomto pozadí vynikne Platónův zásah do intelektuální tradice 5. století. A to jak platónská konstrukce rétoriky coby nauky o mimo-informativním stylu a protějšku metafyzického vědění, tak jeho vyprávění o počátcích této nové disciplíny, pomíjející reálné kosmologické zájmy „sofistư“ a navazující vlastní rétorickou teorii na logografickou „advokátní“ praxi jinak neznámých sicilských původců. Jen jakési symbolické uznání role anaxagorovských kosmologů můžeme vidět v tom, když Platón ve svém pozdním programovém formulování vzájemného vztahu rétoriky a filosofie, kdy je takto definovaná rétorika začleněna do nově reformulované metafyzické filosofie (resp. jí podřazena), připíše Anaxagorovi čestnou roli učitele ,ze všech nejdokonalejšího“ rétora minulosti - Periklea..$^{5}$

95 Viz Platón, Phaedr. 269e1. Na problematičnost Platónova vyprávění o sicilském objevu rétoriky, které se stalo součástí antické rétorické doxografie, upozorňuje E. Schiappa, The Beginnings, str. 30-47. - Vznik této studie byl podpořen GA UK (projekt č. 1428217), jehož příjmcem byla Katedra filosofie a dějin přírodních věd PřF UK. 


\section{ZUSAMMENFASSUNG}

Diese Studie setzt mit Argumenten an, auf die sich die bekannte Interpretation von Th. Cole und L. Schiappa über den Einfluss Platons auf die Entstehung einer Theorie der Rhetorik im alten Griechenland stützt. Dieser Interpretation nach wurde die Theorie der Rhetorik als einer speziellen Disziplin durch ihre Herkunft in der metaphysischen Philosophie ermöglicht, die einen theoretischen Grundrahmen entwirft, in dem die theoretische Rhetorik eingebettet werden kann: als eine formale Disziplin, die die über bloße Informationen hinaus gehende Dimension des logos (Stil) betrifft und zwar außerhalb des wahren, informativen Wissens über die Dinge, das in logos (Philosophie) reflektiert wird. Dann diskutieren wir vier Abhandlungen, die in der Hippokratischen Sammlung enthalten sind: De carnibus, De flatibus, De arte und De vetere medicina (meistens in Form von gesprochener Sprache geschrieben und somit werden sie als rhetorische Hippokratische Schriften klassifiziert). Unsere Aufmerksamkeit konzentrieren wir auf die reflexiven Verfahrensweisen und auf die Terminologie, die die Autoren verwenden, um sich auf den Aufbau des Textes selbst zu beziehen. Dieses reflexive Merkmal, das Form und Inhalt des Textes umfasst, wird mit dem Begriff hupothesis oder mit dem Verb hupotithesthai bezeichnet. Überraschenderweise bezeichnet derselbe Begriff hupothesis die allwissende und alles durchdringende, materiell gewordene kosmische Vernunft. Dieses den Kosmos strukturierendes Prinzip, bekannt seit der späten ionischen Kosmologie eines Anaxagoras von Klazomenai, Archelaos von Athen und Diogenes von Apollonia, funktioniert somit auch als ein den Text strukturierendes Prinzip. Diese die Zusammensetzung betreffende Funktion kann man in der parallelen Struktur der Abhandlungen De carnibus und De flatibus beobachten, in denen das kosmologische Prinzip seine Gültigkeit in dem Maß bestätigt, in dem es sich als fähig zeigt, alle partiellen Themen in einem kosmologischen Narrativ zu verkörpern, der charakteristisch für den breiten enzyklopädischen Rahmen des vor-metaphysischen griechischen Denkens gewesen ist. Auf der anderen Seite macht nur die Rede die kausalen und die anderen Verbindungen zwischen den partiellen Gegenständen und Strukturen offensichtlich. Diese Methode, die unsichtbaren Gegenstände sichtbar und beobachtbar zu machen mit den Mitteln der Rede, ist ein wichtiger Teil des Selbstverständnisses der frühen griechischen Rhetorik geworden. In einer ähnlichen Art und Weise, diente die alles regierende Macht der kosmischen Vernunft als ein Vorbild für die universelle Macht der Rede, wie von Gorgias gepriesen wird. So war 
die späte „Anaxagorische“ Phase der griechischen Kosmologie eine eindeutige diskursive Praxis, eine reflektierte Art und Weise, wie eine „körperliche" Prosa konstruiert wird. Platons später Versuch, die Rhetorik als eine spezielle formale Disziplin neu zu formulieren und sie der neuen metaphysischen Philosophie unterzuordnen, vernachlässigt weitgehend diesen diskursiven Zug der späten Kosmologie.

\section{SUMMARY}

The study begins with the arguments used by Th. Cole and L. Schiappa for their well-known position regarding Plato's influence upon the genesis of theory of rhetoric in ancient Greece. According to Cole and Schiappa, theory of rhetoric as a special discipline was made possible by the birth of metaphysical philosophy and its outlining of a basic theoretical frame in which theoretical rhetoric could be placed as a formal discipline pertaining to the extra-informative dimension of logos-as-style aside from the true, informative knowledge of things reflected in logos-as-philosophy. Subsequently the article discusses four treatises preserved in the Hippocratic collection: these are the De carnibus, De flatibus, De arte and De vetere medicina (mostly written in the form of a speech, and thus classified as rhetorical Hippocratic writings). We focus our attention on the reflexive procedures and terminology which the authors use to refer to the construction of the text itself. This reflexive feature, embracing both the form and the content of a text, is captured by the term hupothesis and the verb hupotithesthai. Surprisingly, the same term hupothesis denotes the all-knowing and all-pervading materialized cosmic mind. This cosmos-structuring principle, known from the late Ionic cosmology of Anaxagoras of Clazomenae, Archelaus of Athens and Diogenes of Apollonia, thus also functions as a text-structuring principle. This compositional function can be observed in the parallel texture of the treatises De carnibus and De flatibus, where the cosmological principle certifies its validity insofar as it is able to embody in a cosmological narrative all the partial topics characteristic for the broad encyclopaedic scope of Greek pre-metaphysical thought. On the other hand, only speech makes obvious the causal and other connections between partial things and structures. This method of making invisible things visible and observable by means of speech became an important part of the self-understanding of early Greek rhetoric. Similarly, the all-governing power of the cosmic mind served as a model for the universal power of speech, 
lauded by Gorgias. Thus, the late "Anaxagorean" phase of Greek cosmology was a clearly discursive practice, a reflected way of constructing a "physical" prose. Plato's later attempt to reformulate rhetoric as a special formal discipline and to subordinate it to the new metaphysical philosophy largely neglects this discursive feature of late cosmology. 